\title{
Stanisław Kostka Potocki i mowa ku czci poległych w roku 1809
}

Jacek Wójcicki 
nAPTS Seria IX 2003

\section{Jacek Wójcicki}

\section{Stanisław Kostka Potocki i mowa ku czci poległych w roku 1809}

Czasem warto sięgnąć do schematów starych a sprawdzonych. Zacznijuny więc od przywolania średniowiecznego wiersza „ku panięci”:

Quis? Quid? Ubi? Quibus anxilits? Cur? Quonodo? Quando?

— by, odpowiadając na pytania „Kto? Co? Gdzie? Za pomocą czego, przy czyjej pomocy? Dlaczego? W jaki sposób? Kiedy?”', opisać postawione na wstępie zagadnienie.

Jego dość ogólny ksztalt pragnic podkreślić mimowolną doskonatość tytulowej formuly pierwodrukı dzieła, które jest przedmiotem naszego zainteresowania. W istocie, Pochuała ualeczuych Polakóu' u' ostatnicju'ojnic polegtych byta „czytana... przez Stanisława Potockiego”, ale stanowiła jego dzieło autorskie tylko w takim stopniu, w jakim zasługą mówcy jest zawsze nadanie porządku skladnikom przewidzianym przez reguly retoryki i dostarczonym przez szeroko pojęte okoliczności zewnętrzne. To oczywiście zasłıga wiclka i niepodważalna, w przypadku Potockiego ugruntowana mocno na znawstwie teorii i wieloletnim doświadczeniu. Ale liczba i charakter owych części składowych, a także dalsze przemiany wygłoszonego już przez niego tekstu kazały zawahać się w użyciu typowego oznaczenia odpowiedzialności w nagłówku niniejszego szkicu.

Mówiąc krótko: nie byla to tylko i po prostu, ,mowa Stanisława Potockiego". Przy bliższym oglądzie Pochu'ała... jawi się jako paradoks, byt nieoczywisty, i niemal na równi ze swoim autorem podległy ciśnicniu epoki.

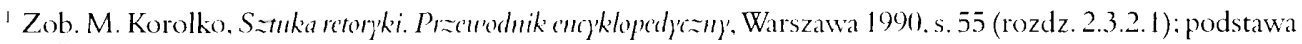
terminologii retorycznej używanej $w$ dalszym ciagu artykulu. 
Tu właśnie przyda siç mnemotechniczny heksametr, dzięki któremu - zmieniwszy nieco kolejność pytań - uda się, być może, określić kierunek i siłę oddziaływania życia na mówcę oraz sposoby i cele prób wplywu mówcy na życie samo.

Nie każde pytanie prowadzi do paradoksów i nie wszystkie domagają się równie szczególowych odpowiedzi. Nie mamy bowiem do czynienia z problemem atrybucji tekstu anonimowego ani z mistyfikacja autorską, która zmuszałaby do rozgalęzionych poszukiwań archiwalnych. Material porównawczy latwo zgromadzić. Szczęśliwym zbiegiem okoliczności zachowały się nie tylko liczne egzemplarze kilku edycji mowy², lecz także przetrwalo Archiwum Publiczne Potockich, źródlo istotnych w tym zakresie, niewykorzystanych dotychczas badawczo dokumentów rękopiśmiennych ${ }^{3}$.

\section{Quis?}

Karta tytułowa wydania z 1810 roku dość szczegółowo wymienia godności mówcy:

...przez Stanislawa Potockiego, senatora wojewodę, prezesa Rady Stanu i Ministrów oraz Izby Edukacyi Publicznej, komendanta jeneralnego korpusów kadeckich, czlonka Towarzystwa Królewskiego Przyjaciół Nauk, orderów polskich j Legiji I Ionorowej kawalera.

Urodzony w 1755 roku mówca i polityk, wychowanek pijarskiego Colleginm Nobilimm, jeden z najaktywniejszych uczestników Sejmu Czteroletniego, za Targowicy zbrojny obrońca Konstytucji 3 Maja, więzień Austriaków; mecenas artystów i kolekcjoner dzieł sztuki, od początku stulecia whaściciel Wilanowa; wspóltwórca Towarzystwa Przyjaciól Nauk i organizator szkolnictwa; teoretyk i historyk literatury, pisarz i krytyk literacki; wolnomularz — nie było w zasadzie dziedziny życia publicznego Księstwa Warszawskiego, w której Stanisław Kostka Potocki nie brałby niezwykle znaczącego udziałuł. Podjęcie się przezeń wygłoszenia mowy

\footnotetext{
2 Picrwodruk: S. K. Potocki. Podhuata unalecznych Polakónu w ustatnicj wojnic polestych..., Warszawa [b. dr.]. 1810.

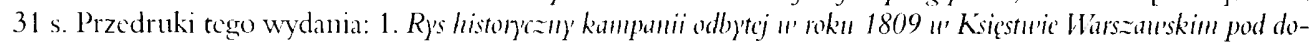

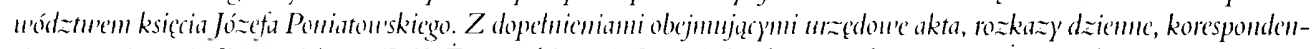
cje, mou') i poczje. Poznań 1869 (J. K. Żupański), s. 1+3-164: 2. idem, Kraków 1889 (Żupański i Heumann, seria: Nowa Bibliotcka Uniwersalna); ..wyd. wznowionc"| tj. okladkowe]: Kraków 1905 (Spólka Wydawnicza Polska). s. 163-188. Wydania nastẹpne: ..Roczniki Towarzystwa Królewskicgo Warszawskicgo Przyjaciól

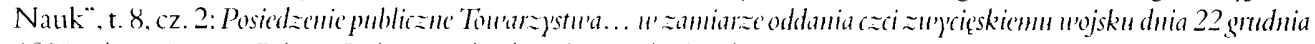

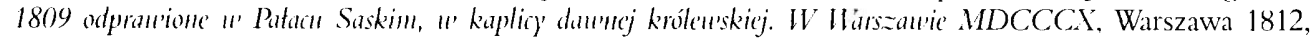

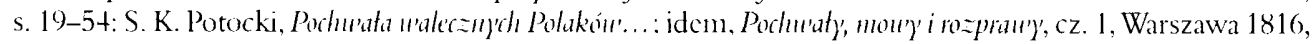

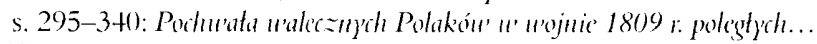

${ }^{3}$ Zob. Archiwum Głównc Akt Dawnych w Warszawic - Archiw'un Publiczne Potockich, rps AGAD ApP

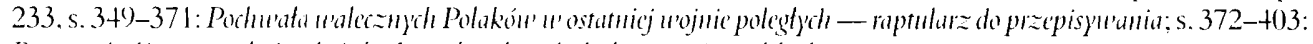

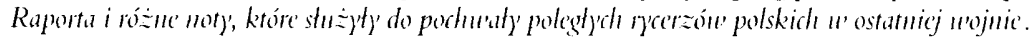

+Znowszych opracowan zob. B. Grochulska. Stanistun' Kostke Potocki (1755-1821). w: Pisarze polskicgo ośl'iecemiu. red. T. Kostkicwiczowa. Z. Goliniski. t. 3. Warszawa 1996, s. 14)-172 (biogram, bibliografia i fragmenty utworów literackich). Zob. tez weześnicjsze prace Zdzisława Libery: Stanistau Kostku Potocki jako pisatrz i kryt)k

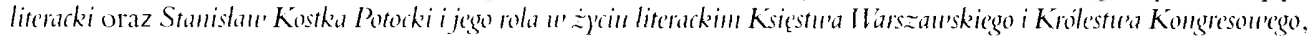


nobilitowato jej przedmiot, a sama mowa nabierała charakteru oficjalnej wykładni polityki wladz (jeśli odnosiła się do zagadnień państwowych lub edukacyjnych) albo nieodwołalnego werdyktu estetyczno-moralnego (jeżeli oceniała osoby i ich zasługi).

Nic zatem nie zaskakuje nas na wstępie. Wątpliwości odnośnie statusu ontologicznego „Stanisława Potockiego” jako mówcy nie odnoszą się do jego odpowiedziahności autorskiej „pierwszego rzędu” - zachowane rękopisy jasno pokazują, że jakakolwiek pomoc sekretarzy i kopistów była wyłącznie techniczna, a liczba wariantów i brulionów dowodzi rzetelności w pracy nad swoimi - i tylko swoimi - tekstami ${ }^{5}$. Chodzi raczej o zjawisko natury duchowej, i to w odniesieniu do przemian tekstu wyjściowego, związane z atmosferąjego czasów.

\section{Quando?}

Czas określony został w tytule pierwszego wydania Pochu'aty'.. bardzo precyzyjnie: 22 grudnia 1809 roku, a więc, by tak rzec, , w oktawie” uroczystego powitania wojska polskiego, które powrócilo do stolicy Księstwa przed kilkoma dniani. Wydarzeniu temu towarzyszył szereg tekstów okolicznościowych. Tradycyjnie niejako zabrał głos „winszujący wierszopis” Marcin Molski, a podpisując utwór pod bezbarwnym tytulem Do wojska narodowego pouracajacego do Warszan')' po u'ojnie austryjackicj 18 grudnia 18(99, nie omieszkał po swoim nazwisku odnotować szarży pulkownika. W epickim wierszu, który jest wlaściwie rymowaną kroniczką kluczowych zmagań wojennych, Molski, nie bez lekkości i poczucia humoru, opisywał zarówno ważne zdarzenia, przywolując nazwiska wybitniejszych dowódców nieprzyjaciclskich, jak i drobne obyczajowe detale (nawet kwitując w przypisach gazetowe źródło informacji!), świadczące o minionym austriackim ucisku. Zupełnie inną, nasyconą mitologicznymi porównaniami Odę na pourrót u'ojska polskiego do stolicy'... przygotował Franciszek Wężyk, wznosząc ton na wzór "rzymskich” i „cezariańskich” ód I Ioracego" oraz autorów klasycznych ód francuskich, Jana Baptysty Rousseau i Jana Jakuba Lefranc de Pompignan. Podobnie, choć z większym udziałem realiów rodzimych, postąpil inny przedstawiciel ówczesnej literatury oficjalnej, Ludwik Osiński, w Wierszu na pourót zu')'ięskiego n'ojska do stolic)' .

Spośród wybitniejszych ówczesnych poetów nie oglosil wtedy w Warszawie stosownego wiersza Kajetan Koźmian. Można go jednak usprawiedliwić, ponieważ, przebywając wówczas w Lubelskiem, od początku kampanii galicyjskiej towarzyszył wprowadzaniu przejściowej administracji francuskiej nie tylko solennymi odami, lecz także .przestrogami dla ziomków" (z akcentami satyrycznymi skierowanymi przeciw biurokracji), a wydarzenie

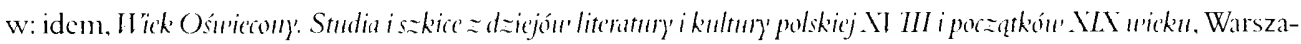
wa 1986, s. 313-325, 326-339.

${ }^{5}$ W stosunku do poczji zauważyła to już Jadwiga Rudnicka, zob. cadem. Informagja o wrierszah Stanistan'u Kosthi Potockicgo, ,Paniçtnik Litcracki” LV. 19)(14. z. 2. s. 482.

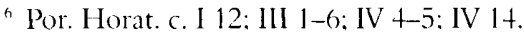

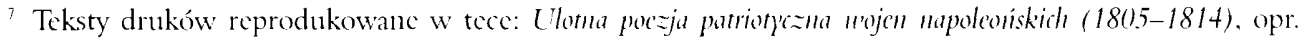
A. Zicliniski, Wrockaw 1977, nr 6-8. 
o znaczeniu ponadlokalnym, czyli zawarcie pokoju francusko-austriackiego w Schönbrunı 14 paździemika, uczcil kolejną w swoim dorobku „odą napoleoníską”, jeszcze dobre kilka lat przed mającym dopiero nadciagnąć "upadkiem dumnego"”.

Jednak, odpowiadając ogólniej na pytanie „kiedy”, należy zaznaczyć przede wszystkim, że Stanisław Potocki glosil pochwalę poległych żohnierzy po zakończeniu niezwyklej kampanii militarnej, o znaczeniu wykraczającym daleko poza doraźne korzyści wojskowe. Byla to bowiem pierwsza wojna. w której organizująca się jeszcze armia Księstwa Warszawskiego, satelickiego wobec Francji państewka buforowego, stworzonego dwa lata wcześniej na mocy układı w Tylży między carem Aleksandrem I i cesarzem Francuzów, samodzielnie stawila czoło kilkakrotnie liczniejszemu wojsku austriackiemu, i walkę tę wygrała, odzyskując nawet zbrojnie na Austrii ziemie trzeciego (i częściowo pierwszego) zaboru" ${ }^{11}$. W tych okolicznościach uroczyste wkroczenie do Warszawy (zajętej przez Austriaków na początku działań wojennych, na podstawie kapitulacji po nierozstrzygniętej bitwie pod Raszynem 19 kwietnia", a opuszczonej przez nich chylkiem w nocy z 1 na 2 czerwca) oddziałów polskich, które metodą faktów dokonanych, ratyfikowanych w Schönbrumn, wzbogaciły Księstwo o cztery nowe departamenty galicyjskie, miało znaczenie symboliczne. W powszechnym odczuciu Księstwo, pod oktrojowaną nazwą, niesamodzielnym rządem i kuratclą francuską, zobowiązane do gigantycznego wysilku finansowego, aprowizacyjnego i militarnego, przez Napoleona traktowane jako miçkka karta przetargowa w jakichkolwiek przyszlych negocjacjach międzynarodowych, a przez Austriaków postrzegane jako latwe do zdobycia terytorium dywersji na marginesie zasadıiczego teatru wojny nad Dınajem - było już Polską idącą ku odzyskaniu niepodległości, z nieoficjalną stolicą duchową w zajętym whaśnie starodawnym Krakowie, ale administracyjną i kulturalną w Warszawie.

\section{Ubi?}

Zatem wlaśnie w Warszawie, już od początku okupacji pruskiej starającej się nie wypaść ze stolecznej roli przynajmniej w dziedzinie kultury (by wymienić choćby działalność Teatru Narodowego, a od 1800 roku - Towarzystwa Przyjaciół Nauk), odbyła się uroczystość, zamykająca akcentem intelektualıym kilkudniowe publiczne obchody związane z ustanowio-

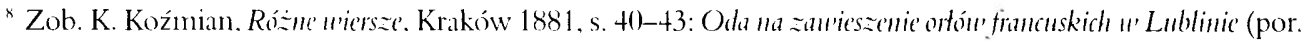

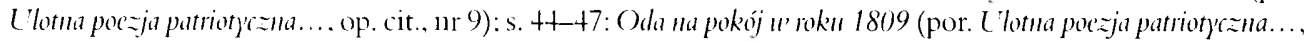

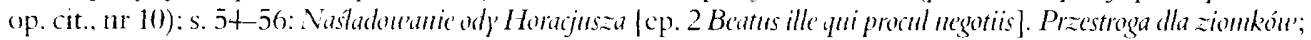

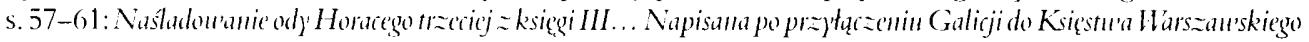

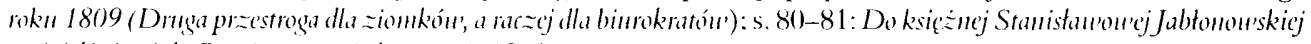

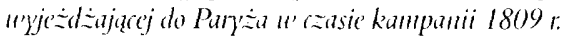

"Zob. ibidem, s. 91-93: Oda na upadek dummego u' roku 1815. Zob. tez: P. Żbikowski, Kajetan Kuźmian. I: Poeta ioby'uratel 1797-1814). Wroclaw 1972 (Studia z Okresu Oświecenia.t. 12), rozdz. IV: Ody'napolconiskic Koźmia-

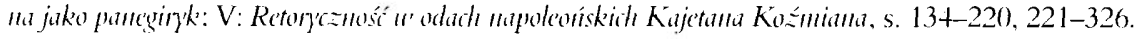

1" Zob. monogratic: B. Pawtowski. Ilónna polsko-anstriacka 1809. Warszawa 1999 (O Wolność i Nicpodleglość) [I wyd.: 1935]: B. (irochulska. Kisigstmo ILarszantskic. Warszawa 1991 (Biblioteka Wiedzy Historycznej).

"Zob. zarys monograficzny: R. Romański, Ruzi)" 1809, Warszawa 1997 (H Historyczne Bitwy).
} 
nym waśnie świętem narodowym z okazji przyłączenia do Księstwa departamentów galicyjskich. Miejsce wygłoszenia mowy Potockiego precyzuje wydanie z 1812 roku: „w Pałacu Saskim, w kaplicy dawnej królewskiej”. Aula ta nie slużyła wówczas kultowi religijnemu, a oficjalne uroczystości kościelne odbywały się swoim trybem w świątyniach stolicy. Być może jednak ze względu na poprzedni charakter miejsca i rodzaj zebrania należy użyty w tytule powyższego wydania imiesłów „odprawione”, clement normalnego zwrotu frazeologicznego, odczytywać nie tylko w świeckim kontekście?

\section{Quid?}

Karta tytułowa publikacji 1812 oznajmia bowiem, iz jej zawartość dokumentować ma Posiedzenie publiczne Tou'arzystu'a Króleuskiego Warszanskicgo Przyjaciót Nauk u'zamiarze oddania czcizu'ycięskicmmu wojsku... odprau'ionc'... a więc coś więcej niz tylko sesję naukowo-popularyzatorską, z rzędu tych, które zawsze cieszyły się zainteresowaniem publiczności jako jedna z nielicznych trybun względnie swobodnego słowa ojczystego. O wadze przedsięwzięcia świadczy fakt, że jego plon tekstowy zasłużyl w wydaniu z roku 1812 na osobną część ósmego tomu „Roczników TPN” i oddzielną kartę tytulową (z datą 1810).

Z zawartości tomu orientujemy się, ze uroczystość musiala trwać niemal caly dzień. Posiedzenie zagaił prezes TPN Stanislaw Staszic (wyd. 1812: s. 1-18), a w części zasadniczej wygłoszone zostały trzy elogia. Charakter najogólniejszy miała pierwsza w kolejności Pochurata u'aleczmych Polakóu'... Potockiego (s. 19-54). Druga pośmiertna laudacja (s. 55-10()) dotyczyla jednej tylko osoby, wybitnego czlonka Towarzystwa, ale zarazem postaci powszechnie znanej, symbolizującej jedność wysokich walorów duchowych i żołnierskiej ofiarności w ojczystej potrzebie: Pochuratę Cypriana Godebskiego, poleglego w ostatniej fazie bitwy pod Raszynem, wygłosil filozof Józef Kalasanty Szaniawski (ten sam, który później, za czasów Królestwa Kongresowego, w niesławie będzie „cenzırować książki i obrazki”). Czwartym mówcą był Julian Ursyn Niemcewicz, któremu powierzono Podmutę pogrzebou'a Ignacego Potockiego (s. 101-122), brata Stanisława Kostki i prestiżem równej mu ówcześnie persony, zmarłego nagle 30 sierpnia w Wiedniu, dokąd jako wysłannik Polaków ze świeżo oswobodzonej Galicji udał się na rozmowy z Napoleonem w sprawie przylaczzenia tych ziem do Księstwa' ${ }^{12}$.

Tu zakoníczono część retoryczną. Przedostatnim punktem programu bylo odczytanie wspomnianego już wiersza Ludwika Osińskiego (s. 123-127). Zanim jednak zamknięto uroczystość występem muzyków, z wierszem ex promuptu (tak to w każdym razie miało wygląać) w języku Racine’a i Corneille’a dał się slyszeć ówczesny rezydent francuski Jean Charles Serra

\footnotetext{
12 "Przemowa jego do bolatera byla krótki i prawic w tych stowach, jak mówiono, zawarta: "Wiclki cesarzu! nicch siç stanic wola twoja. rzcknij stowo. a Polska powstanic»" (K. Koźmian, Pamiçtmiki, wst, i koment. ). Willaume, opr tekstu M. Kaczmarck i K. Pecold. t. 2. Wroclaw 1972. s. 35). Koźmian, dla kitorego .Ignacy Potocki byl z cnoty, rozumu, nauki. patriotyzmu, siły i ţ̧gości duszy nạznakomitszym mężem w ciągu panowania Stanislawa Augusta” (ibidem, s. 32). przytacza pogkoski, jakoby delegacja polska, niczalcżnie od panujacej w Wiedniu cpidemii. padla ofiarą próby otrucia (ibidem, s. 36: oprócz I. lotockiego, który nic przezyl, chorowat i Tadeusz Matuszewicz. i Ignacy Miączyniski).
} 
(z pochodzenia Genueńczyk), ceniony ze względu na walory towarzyskie i talent pisarski przez środowisko warszawskich literatów ${ }^{13}$. Wiersz wraz z prozaicznym przekładem polskim i opisem żywej reakcji zgromadzonej publiczności, zwłaszcza pań, zamieszczono na s. 127-128, tuż przed krótkim opisem koncertu.

Warto ten anonimowy opis przypomnieć jako intrygująca antecedencję Mickiewiczowskiego koncertu Jankiela w Panu Tadeuszu:

Posiedzenie Towarzystwa zakończone zostało muzyką JP Józefa Elsnera, czlonka zgromadzenia. Autor napisał inarsz tryumfalny na powrót zwycięskiego wojska. Myślą jego bylo przypomnieć w muzyce pamiętniejsze epoki w narodzie, które tak ściśle łączą się z dzisiejszą. Wykonal to przez rzucone szczęśliwie wśród muzyki wyjątki śpiewu z marszu znanego pod nazwiskiem Jana III, z tańca przypominającego imię i usiłowania Tadeusza Kościuszki, z marszu znanego pod imieniem Legionów Polskich i ich dowódzcy generała Dąbrowskiego; w zakończeniu dzieła dało się słyszeć tema tańca krakowskiego i przenosiło niejako słuchacza do tej starożytnej stolicy, odzyskanej z taką chwałą oręża polskiego.

Mowa Potockiego była więc częścią starannie zaplanowanej, wzniosłej uroczystości, sytuującej się z socjologicznego punktu widzenia na pograniczu działalności naukowej i obrzędowości świeckiej o charakterze quasi-sakralnym. W tym ksztakcie była to, jak się zdaje, w Polsce rzecz bez precedensu.

\section{Quibus auxiliis?}

Problem wiotkiej granicy między stosownością wymowy świeckiej i sakralnej postawił krótko Potocki przy okazji wznowienia Pochu'aty walecznych Polakón'... w roku 1816:

Zamyka w sobie tenze tom trzy mowy pogrzebowe, przypominające wymowę kazalną, ten jej za czasów naszych rodzaj najszczytniejszy, do którego mówca świecki tym jedynie sposobem zbliżyć się może. Wszelako więcej ograniczonymi są i w tym jego sposoby niż mówcy duchownego; trzeba mu niemałej ostrożności, by nie przestąpił tego delikatnego zakresu, który zachodzi między światową wymową, choć mówiącą w kościele, a duchowną, bo pierwsza wciska się, że tak powiem, do niego, kiedy druga w nim panuje ${ }^{1+}$.

Podobnie jak kaznodzieja, także autor świeckiej mowy pogrzebowej dysponowal szeregiem wzorów, choć rzecz jasna o innym charakterze, sięgających glębokiej starożytności. Sam Potocki w spisanym później dzicle $O$ u'y'mou'ic i sty'lu powoła się w zakresie publicznych uro-

\footnotetext{
${ }^{13}$ Opiniç Koźmiana zob. ibidem. t. 2, s. 121-122. 282: por.: M. Plezia. Zapommiany lacinski dzicjopis Napoleona I, ..Przcgląd Historyczny", t. 82. 1991 z. 3-4. s. 497-503.

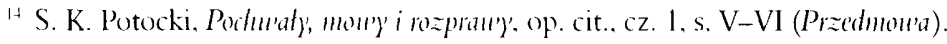


czystości żałobnych na trzech antycznych przodków: Peryklesa, Demostencsa i Platona ${ }^{15}$. Można jednak tę liczbę greckich antenatów podwoić.

$\mathrm{O}$ istnieniu w Atenach dawnego zwyczaju gloszenia pochwal poległych żołnierzy przez wybitnych obywateli podczas uroczystości pogrzebowych na koszt państwa na Keramcjku, połączonych z konkursami muzycznymi i sportowymi, świadczy już Tukidydes, autor Wojny' peloponésiej. On właśnie przytacza (II 35-46) - zgodnie ze swoją koncepcją prawdy historycznej, o której wypadnie wspomnieć jeszcze późnicj - najpiękniejszy, zdanienn licznych badaczy, epitaf, wygloszony na pogrzebie żolnierzy ateńskich zimą pierwszego roku wojny peloponeskiej $\left(431 / 430\right.$ p. 11. e.) przez wielkiego Peryklesa ${ }^{16}$.

Uroczystość tonu, poetyckość i wykwintność języka tej piçknej pochwaly Aten i systemu demokratycznego zwraca nasze spojrzenic w kierunku wielkiego Sycylijczyka ${ }^{17}$.

To słowa o Gorgiaszu z Leontinoj, na którym wzorował się w tej części dzieła Tukidydes - podziwianym i naśladowanym w świecie greckim mistrzu retoryki, w którego dorobku była takze mowa pogrzebowa, napisana ok. 421 r. p. n. e. (gdy zawarty zostal pokój Nikiasza między Atenami i Spartą), zaclowana jedynie we fragnentach ${ }^{1 \times}$ jako druggi przyktad tego gatunku retorycznego z czasów antycznych. Trzecim wedhug chronologii jest epitaf Lizjasza", mowa (napisana, choć nie wiadomo, czy rzeczywiście wówczas wygłoszona) na cześć Ateńczyków, którzy zginçli w wojnie korynckiej 395-387 p. n. e.

Po przegranej bitwie pod Cheroneą w roku 338 p. 11. e., gdy Tebańczyków i Ateńczyków pokonały wojska Filipa Macedońskiego, niezwykle zaszczytny, ale w obliczu klęski ciężki obowiązek pożegnania poleglych powierzono uczestniczącemu w tej bitwie (i nawolującemu do niej!) I emostenesowi, największemu z mówców starożytnej Grecji niepodległej, których znamy ${ }^{211}$. Było to dla niego - jak dla każdego ambitnego mówcy w podobnej sytuacji — jednocześnie trudne zadanie warsztatowe: tchnąć życie w formę ustaloną przez tradycję. W porównaniu z innymi jego mowami epitaf cheronejski stwarza wrażenie nieco chłodnego i bezbarwnego. Dzicli jednak te cechy z resztą zachowanych mów pogrzebowych antyku, którym z tych właśnie względów przeczono autentyczności. Nie ominęlo to także Demostenesa,jednak przeważają dziś argumenty za jego autorstwem epitafiı. Oprócz dowodów czysto filologicznych są wśród nich równiez przesłanki tréściowe:

15 Zob. idem. O "')mouric i stj/m. Warszawa 1815. cz. 1. t. 2. s. 117-121.

in Zob. R. Turasicwicz. Ilstep w: Tukidydes, Ilojmapeloponeska. tl. K. Kumaniccki, opr. R. Turasicwicz, Wrocław (BN II 225), s. LXXI-LXXXII: „... wiçkszość nczonych wysuwa wniosck, iz Tukidydes ulożyl Epitaf por. tot p.n.c. (...)" (s. LXXVII).

17 R. Turasicwicz. Hstep. w: Demostenes, Hyir món, tl. i opr. R. Turasicwicz. Wroclaw 149)1 (BN II 15). s. LXXV.

* Charakterystyka wymowy Gorgiasza zob. ibidem. s. LXV-LXXIV.

${ }^{14}$ Zob. Mou'a pogrzebou'a, w: Lizjasz. Mou'y, tl. iopr. R. Turasiewicz, Kraków 1098 (Biblioteka Przckladów z Literatury Antyczncj. nr 11), s. 12-26.

211 Zob. Demostenes, Mou'a pogrzedou'a, w: idem. Ifyer món, op. cit.. s. 169-183. 
Gorąca pochwała demokracji i wolności słowa, całej polityki Aten wobec innych państw - której znaczenia nie pomniejsza przegrana - mitologizacja świetnej przeszłości ojczyzny i heroizacja poległych za nią żołnierzy, nie są wspólnym dobrem wszystkich epitafów, lecz stanowią własność tego jednego, który wypowiada ostatni obrońca demokracji ${ }^{21}$.

Za ostatni grecki epitaf bezpośrednio związany z rzeczywistymi okolicznościami politycznymi uznaje się utwór Iyperejdesa, przyjaciela, a potem zażartego rywala Demostenesa. Jest to mowa pogrzebowa poleglych w wyzwoleńczej wojnie lamijskiej przeciw Macedonii $(323-322 \text { p.n.e. })^{22}$.

Osobne miejsce należy się szeroko dyskutowanemu wśród uczonych dialogowi Platona Meneksenus, powstalemu już po otwarciu przezeń Akademii (okolo roku 387 p. n. e.) i po zawarciu niesławnego pokoju Antalkidasa między Spartą a Persami (r. 386), co prowadzi do jawnego anachronizmu, gdy czyni do niego aluzję nieżyjący od trzynastu lat Sokrates ${ }^{23}$. Dialog, którego treścią jest dyskusja filozofa z tytulowym młodzieńcem na temat zasad wygłaszania mów pogrzebowych, to jednak konstrukcja literacka świadomie fikcyjna i kunsztowna. W zasadniczej części dialogu Sokrates wyglasza typową mowę pogrzebową, powtarzając jakoby tylko to, co usłyszal od swojej nauczycielki wymowy Aspazji, żony Peryklesa — a w samej nowie z kolei dochodzą do glosu zmarli, apelıjący do dzieci o praktykowanie cnoty i proszący rodziców o powstrzymanie się od zalı. Wyrazem uznania, z jakim mowa ta, a zwłaszcza jej zakończenie, spotkata się u wielu krytyków, mogą być słowa Stanisława Potockiego z roz-

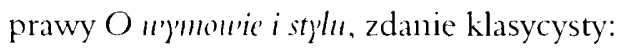

Trzeba czytać ten kawalek w samym źrzódle; ciężko bowiem jest znaleźć coś szlachetniejszego w wymowie i bardziej ożywionego tą miłością ojczyzny, i tym zachwyceniem wolności, co były prawie powszechnym dawnych mówców duchemint $^{2+}$.

Mimo tak pochlebnych dla talentu retorycznego Platona ocen nie sposób oprzeć się wrażeniu, że wprowadzona przez niego w Sokratesowym epitafie wielość mówiących pośredników ma podkreślać dystans autora do prezentowanych zagadnień. Badacze wciąż się bowiem spierają o cel. który przyświecal Platonowi, wrogowi jałowej sofistyki i efektów retorycznych, przy tworzeniu modelowego, wznioslego epitafu. Uważa się nawet, że to satyra na mowę po-

${ }^{2}$ R. Turasicwicz. H'stẹ. w: ibidem. s. XLIV: ocpitafic zob. s. XLII-XLIV. Wczéśniej podobnic wyrazil się Tadeusz Sinko: „Gdy czytamy pochwalę polityki ateńskicj wobec polityki innych państw, pochwałę ich męstwa, którego stawy przegrana nie uszczupla. a którce powstrzymalo wroga od uderzenia na Ateny i spowodowalo znośny pokój - czujeny telnicuic rzcczywistości - obce cpitafon Lizjasza i Platona“- T. Sinko, Litcratura grecka. t. 1. cz. 2: Literatura klas)rzma (u. I'-II przed Chr.), Kraków 1932, s. 711.

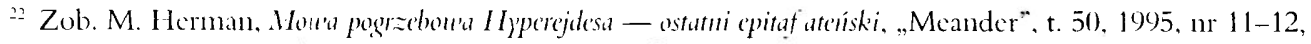
s. 497-5013: R. Turasicwicz. I'step, w: Demostenes. IIjor móll. op. cit., s. XCV-XCVI.

${ }_{23}$ Zob. Platon, Menéksenos, th. i opr. K. Tuszyńska-Macicjewska. Wroclaw 1994 (Bibliotcka Przckladów z Literatury Antyczncj, nr 31).

${ }^{2+}$ S. K. Potocki. O "'ymouric i st $)^{\prime h}$, op. cit., s. 122. 
grzebową, dowód, że ułożenie jej z gotowych klisz nie wymaga żadnego wysiłku. Są jednak u Platona twórcze różnice wobec tradycji. Jego Aspazja-Sokrates rezygnuje z egzemplów mitologicznych, dzielność Ateńczyków ilustrując prawdziwymi przykladani historycznymi; podobnie niemęski lament nad ofiarami wojny zostal zastąpiony pocieszającą przemową samych umarlych (prozopopeja). Byłby to dowód na to, że w planic ideowym dialog mógt być próbą pogodzenia się arystokraty Platona z otaczającą go demokratyczną rzeczywistością. a zarazem w planie literacko-warsztatowym prezentacją możliwości, jakie daje skostnialy niwet gatunek retoryczny (jeśli juz musi istnieć w państwie zwyczaj mów pogrzebowych), pod warunkiem, że mowa będzie umiarkowana w wywoływaniu emocji, a mówca — zdolny i uczciwy ${ }^{25}$.

Wspólne cechy typowego epitafu greckicgo ${ }^{26}$ mówca winien respektować, ale zarazem śladami Platona-Sokratesa-Aspazji - próbować także ich twórczego przelanywania. Do owych „miejsc wspólnych” należalo wyrażenie już na wstępie poczucia niemoźności dorównania bohaterstwu poległych wszelkimi pochwałami. Tak ująt to Demostenes:

...dokładnie uwielbić poległych na placu pamiątkę jest niemal zamysłem ku wykonaniu niepodobnym. Czyliz bowiem nie zostawili wyższej nad wszelką pochwałę cnoty, którzy, pogardziwszy wszczepioną od samego przyrodzenia życia miłością, umierać raczej mężnie niż nadwątlony w czym Grecyi stan widzieć chcieli? ${ }^{27}$

Stałym punktem pochwał była też arete — dziclność Ateníczyków, różna od prostej waleczności, bo ufundowana na zaletach ich wychowania:

...gdybyın w nich same tylko widział męstwo, to pochwaliwszy, przestałbym dalej mówić, ale ponieważ los chcial, aby i szlachetnie urodzeni, i dobrze wychowani do chwały przez wysoką cnotę się ubiegali, nie mogę o tym bez uczynienia onymze krzywdy zamilczecint

Obrońcy ojczyzny są autochtonami, naturalnymi jej dzié́mi - jak ujął to Demostenes — w odróżnienniu od przybranych ${ }^{21}$. Piçkny, uprawiony kraj objęli dziedzictwem po również tutejszych przodkach, których legendarne waleczne czyny mitologizuje się, tak że baśnie nabierają wagi dowodów historycznych. Dzieí dzisiejszy Aten to ludowladztwo - kolejny obiekt laudacji. Rządowi zatem rodziny poleglych zawdzięczać mogą opiekę, a pamięci

${ }^{25}$ Zub. K. Tuszyńska-Macicjewska, Stouro u'stepne, w: ibidem, s. V-IX.: cadem. Platon a retoryka: ad kryt)ki de modedu, Poznań 1996, s. 86-98.

26 Zob. G. A. Kennedy. A No'r History' of Classical Rhetoric, Princeton 1994, s. 21-22.

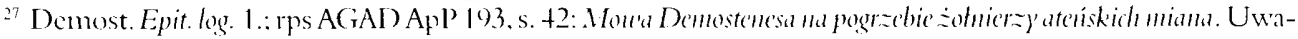
gi o tym przckladzic zob. w dalszcj części artykułu.

-x Demost. Epit. log. 3: rps A(CAD ApP' 193, s. 43.

2" Zob. Donost. Epit. log. $t$. 
o wielkości sprawy, za którą ich synowie oddali życie - pocieszenie po nieuniknionym lamencie.

Stałym elementem epitafu było także podkreślanie przez mówcę krótkiego terminu danego mu na przygotowanie wystapienia. Wprawdzie Sokrates w Platońskim Meneksenosie zauważa ironicznie, że retorzy zawsze mają w zapasie gotowe mowy na taką okazję ${ }^{30}$, ale Potocki — by wrócić już z Grecji do rzeczywistości polskiej - jak się zdaje, istotnie dysponował zaledwie kilkunastoma lub wręcz kilkoma dnianni. Nie wiemy oczywiście, czy pomysł uczczenia poległych nie dojrzewal już na początku listopada lub nawet pod koniec października, gdy sytuacja po pokoju w Schönbrunn stabilizowała się, a perspektywa oficjalnych uroczystości ku czci ofiarnych żołnierzy polskich stawała się oczywista. Ale bruliony nie dają w ogóle podstaw do datowania pierwszych szkiców mowy, a zachowane świadectwa pokazują, że elocutio nie szla przed inlentio. Innymi stowy: mówca pracowal dopiero na konkretnych materiałach, a część dokumentów z kręgów wojskowych nosi daty z drugiej połowy grudnia - niecały tydzień przed uroczystościami TPN!

Jesteśmy bowiem w szczęśliwym położeniu badawczym, mogąc zanalizować warsztat inwencyjny Stanisława Kostki Potockiego. Są nim mianowicie dostarczone drogą służbową oficjalne spisy sztabowe. ulożone

...tak z rozkazów dziennych, fortragów [raportów - J. W.], jako i list imiennych przez dowódzców pulków podanych $(\ldots)^{31}$.

Oprócz rzeczowych w formie, ale nie zawsze bezdusznych (nicktóre emocjonalne frazy z rozkazów Potocki przeniesic bez zmian do Pochu'aty'...) dokumentów sztabowych, potwierdzonych autoryteten dowódców ${ }^{32}$, Raporta i różle not)’... zawierają także świadectwo bardzo osobiste: doniesienie o śmierci młodego szwoleżera spod Somosierry, które z Hiszpanii nadeslał ojcu, pulkownikowi I ziewanowskiemu, Wincenty Krasiński ${ }^{33}$. W piśmie przewodnim oficer zwraca się do Potockiego:

Zob. K. Tuszyńska-Macicjewska. Stow'o w'stepue w: Platon. Mencksenos, op. cit., s. VIII.

Rps A(iAD Apl' 233, s. 381.

32 Rps AGAl) ApP 233 - tu miçdzy innymi: rozkaz pochwalny po bitwic pod Żannowcem 11 lipca szefa sztabu gen. [Stanislawa] Fiszera (kopia), 19 VII 1809 (s. 37+-376); Lista imicmma oficyjerón urojska polskiego "' kampaniji rok'n 1809 polegh fel - tabela obcjmująca okres do sicrpnia 1809 (s. 377-378, 381-382); Lista

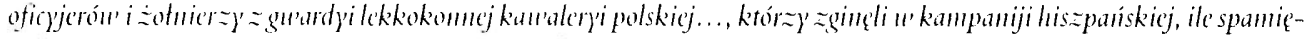
tać mo $̇ m a($ (s. 379)-38()): list majora pulku Strzyzowskicgo z 17 grudnia 1809 z pismem przewodnim (na blankiccie) gen. [Jana Henryka] Dąbrowskiego z 17 XII 1809 (s. 382-384. 385); lista podpisana przez szefa sztabu w czasic wojny. podpulkownika Ignacego Suchodolskicgo, z listem przewodnim gen. [Kajetana] I Hebdowskiego, 23 XI 1809) (s. 391-394); lista podpisana przez pulkownika szcfa sztabu [Antoniego] Cedrowskiego (s. 401).

${ }^{37}$ Ibidcm, list pulkownika [Dominika | D zicwanowskicgo do S. K. Potockicgo oraz zalączony list pulkownika [Wincentego] Krasińskiego do teguż z Tolosy. + II 1809, z wiadomością o śmierci [Jana] Dziewanowskiego, kapitana szwolezorów govardii. 2 grudnia 18018 w szpitalu w Madrycic (s. 386, 387-390). 
...podchlebiam sobie (...), że próżnością nie nazwiesz tego, co może być przykładem dla drugich, a razem i chlubną pamiątką dla rodziców po stracie swojego syna, i w części jakimś pocieszeniem.

Słowa dowódcy są zwięzle, zretoryzowane, choć dalekie od patosu, tchmą jednak jakimś wzruszeniem i prawdą miejsca żohnierskiego trudu:

Przymuszony jestem do spełnienia mojej powinności donieść Jemu, iż syn już Jego nie żyje, dnia 2 decembra z odniesionych ran umarł w Madrycie. Jako ojciec masz Waćpan Dobrodziej prawo plakać; jako obywatel i Polak cieszyć się, że dałeś życie temu, któren go tak clıwalebnie poświęcić umial. Zgon jego okrył go sławą, przynosząc nam smutek. Jam go plakał jak przyjaciela, żolnierze jak ojca, pamięć jego nader nam zawsze drogą będzie. (...) Gdy byl ranny i na placu boju trwał, bijąc się sam, nie moglem mu dać pomocy. Granadyjerowie przyszli od gwardyi, by go z miejsca wziąć; zamiast pozwolić na to, odpowiedzial: „Idźcie do boju, tam jest wasza powinność, jam już mej dopełnil”. (...)

Zamówione materiały wojskowe Potocki wykorzystał bardzo skrupulatmic, o czym oprócz samego tekstu Pochu'ały... świadczą zachowane materiały robocze: spisy nazwisk i wydarzen $^{3+}$ - w tym dwie jednobrzmiące listy notowane pismém różnych rąk, zapewne pod dyktando jednocześnie przez dwóch sekretarzy, co dowodziloby istotnie pośpiechu w przygotowaniu mowy, który nie byl jedynie figurą retoryczną.

Wydaje się, że preparacjanni Stanisława Kostki Potockiego do wygloszenia mowy upamiętniającej poległych w 1809 roku wyjaśnić można obecność w jego papierach jeszcze jednego anxilimm literackiego. Jest nim anonimowy przeklad Mon'y' Demostenesa na pogrzebie żotnierzy atériskich mianej j. Co więcej-można pokusić się o ustalenie, kto byl tego thumaczenia autorem.

Bibliografia przekładów klasyki antycznej czasów stanisławowskich każe od razu zwrócić uwagę na oświeceniowego monopolistę w zakresie polskich tłumaczeń Demostenesa. Urodzony w 1725 roku jezuita Ignacy Nagurczewski ${ }^{36}$ byl nauczycielem wymowy, historii i literatury w kilku szkołach zakonnych, a od 1757 roku - w stołecznym kolegium szlacheckim Societatis Iesu (przybyły tu z Wilna razem z Adamem Naruszewiczem). Następnie, prawdopodobnie od 1769 do 1774 roku, wykladal w starszych klasach stanislawowskicj Szkoły Rycer-

"H Ibidem, s. 373. 395-4(1), 412-4(13.

35 Rps AGAD Apl' 193. s. 42-57.

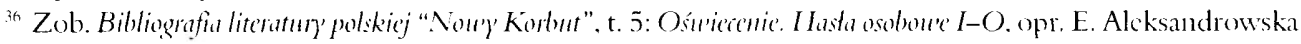

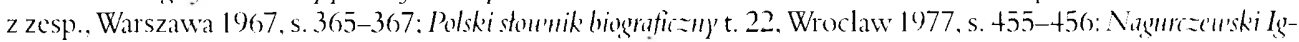

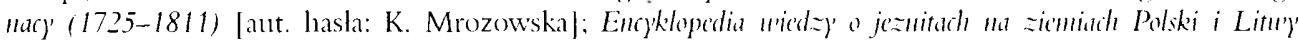
1564-1995, opr. L. Grzehicń SJ i zcsp. jezuitów. Kraków 1996. s. 449. Z wczcśnicjszych biogramów zob.: A. Naruszewicz, życiorys (dat. 30 XI 1780), rps Biblioteki Czartoryskich w Krakowic sygn. 1748 IV, s. 13 (przcdruki: ) .Rozmaitości Warszawskic"1826. ur 31. s. 2+3. z blçdani: E. Rastawiccki, Ston'mik malurzón pol-

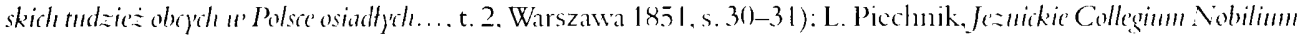
11. Warszauré(1752-1777), .Nasza Przeszłość”, t. 35, 1971 s. 115-152. 
skiejjako pierwszy profesor literatury polskiej. Na wiosnę roku 1778 król powierzyl mu opiekę pedagogiczną nad księciem Józefem Poniatowskim ${ }^{37}$. W marcı 1803 roku został mianowany członkiem przybranym Towarzystwa Przyjaciół Nauk ${ }^{38}$. Zmarł w lutym roku 1811. Niebawem tradycyjų mowę wspomnieniową poświęcil mu nowo przyjęty do TPN Kajetan Koźmian ${ }^{36}$.

Nagurczewski opublikował w 1774 roku tom sześciu mów Ateńczyka ${ }^{40}$. Wstępem historycznym — „na żądanic króla”, jak podkreśla (tym razem w charakterze przygodnego biografa uczestników obiadów czwartkowych) Adam Naruszewicz ${ }^{41}$ - zbiór ten opatrzyl sam mlody Ignacy Potocki.

.Owiec Maronowych z Nagurek dozorca”"2 miał zresztąjuż w 1763 roku gotowy zestaw thumaczeń Demostenesa,

...które od młodzi krasomówskicj byly mówione i do druku w innym czasie będą podane ${ }^{+3}$.

choć na opublikowanej przezeń liścic Mou')' pogrzebou'ej nie ma. Można to jednak wyttumaczyć faktem, że Epitaphios logos krytyka traktowala dlugo jako dzieło nieautentyczne ${ }^{+t}$.

7 Źródla i opracowania nie podają jednoznacznic terminu pracy Nagurczewskicgo w Korpusic Kadetów: Kamilla Mrozowska jako daty startowe przywoluje zarów'no „paździcrnik 1769". jak i ,rok szkolny 1768,1769”. Konice zatrudnicnia (podobnic jak bliski i zapewne dobrze poinformowany kolega i konfrater Nagurczewskiego. Adam Naruszewicz) sytuuje po kasacic zakonul. w roku 1774 - zob. K. Mrozowska. Szkola Ryerska Stanistan'a. Angustu Pontunourskiego (176.5-1794). Wroclaw 1961 (Monografic Pedagogicznc, t. 8), s. 163-164. Ks. Jan Poplatek twierdzi z kolci. że thumacz zaprzestal pracy profesora. dopiero gdy poświçcil się opiece nad ks.

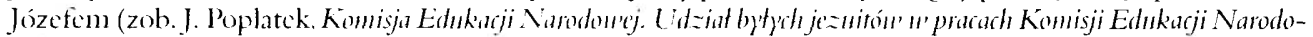
urej. uzup. L. Grzchien SJ. przyg. do dr. J. Paszenda SI. Kraków 1973; s. 104). Nicścistości mogą. jak się zdaje, wynikać z faktu. że Nagurczewski wykładal jakiś czas równolegle w kolegium jezuickim i Szkole Rycerskicj (zarazem jeżdząc nawet do Krakowa na konsultacje w jezuickim seminarimn nauczyciclskim), a w Pałacu Kazimicrzowskim. siedzibic Korpusic Kadetów. mieszkal dożywotnio.

3* Zob. rps AGAD TPN 59: Dzicmuik posiedzeri ogrólnych... (1802-1810). s. 15-17.

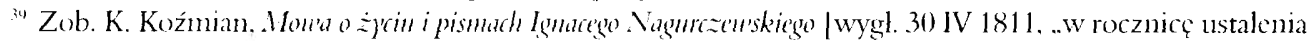
Towarzystwa”. na posiedzeniu Tl'N; autor podajc blçdną datç urodzenia 1819]. .Roczniki Towarzystwa Królewskicgo Warszawskiego Przyjaciól Nauk", t. 9. Warszawa 1816. s. 233-250); przedruk: idem, Pisma prozq, Kraków 1888. s. 131-146.

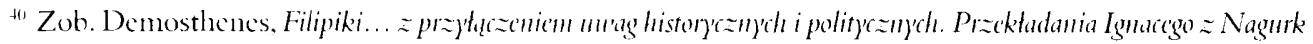
Nugurzen'skiego..., t. 1. Warszawa 177t: wiçcej tomów nic wyszto. Zaw:: filipika I-II, mowa olintyjska I-III, Moura o pokojin.

t1 Rps 13. Czart. $17+8$ IV. s. 21 (życiorys Ignacego Potockicgo, 26 XI 1780).

42 Określenic Adana Naruszewicza z siclanki Oczckin'ane pasterza nu tourarzyszólu (w. 209).

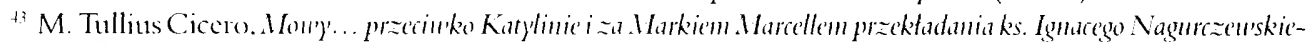
g0.... Warszawa 176.3.s. [138]: z pozycji wymicnionych w spisic nie opublikowano nigdy: dwóch fïlipik, Mou' ${ }^{\prime}$

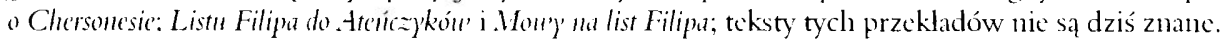

+t Zob. R. Turasicwicz, II step, w: I emostenes, If jér món', op. cit., s. XLIII-XIIV: tu także krótka wzmianka o .Nagórczewskim” (s. (XXIV). Autentyczności Epitatiu przeczyl autor I wyd. tomu BN II 15 , gdzic mowy tej

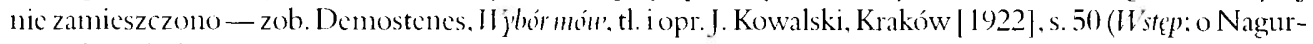
czowskim ibidem. s. 62-633). 
Dlatego jesteśmy w stanie wyobrazić sobie, że sędziwy tłumacz, który sfinalizowal już (bądź porzucił) obszerne przekłady I Ioracego ${ }^{+5}$ i I Iomera ${ }^{t 6}$, po czym wrócil, może z myślą skompletowania tomu wszystkich mów, do pommicjszych pism bliskiego mu autora greckiego $^{+7}$, dostarczył senatorowi wojewodzie, najpewniej z własnej woli, ten „piękny wzór” do planowanego epitafu poległych żohnierzy, wojujących pod dowództwem jego kłopotliwego niegdyś, dziś bohaterskiego wychowanka, księcia Józefa.

Gwoli prawdzie należy jednak odnotować, że opinia Stanisława Kostki Potockiego o przekladach Nagurczewskiego, którą podzielano dość powszechnie, nie była najpochlebniejsza. Jeszcze w satyrze na obiady czwartkowe, zachowancj w trzech wariantach rękopiśmicnnych, Potocki twierdzi, że

Nagurczewski Homera tylko że imienia

Nie pozbawił, piękności nie zostawił cienia,

A gdy u niego I Iektor karocą się włóczy,

Demosten jak bernardyn na ambonie huczy ${ }^{\text {th }}$

- a późniejszy, przeznaczony już do szerszego rozpowszechnienia biogram tłumacza kończy następująco:

Więcej on w tych pracach znajomości dawnych języków niż dobrego smaku w wlasnym okazal ${ }^{+\prime}$.

\footnotetext{
${ }^{45}$ Przypisuję autorstwo przckład ı Listóu I Horacego z rękopisu liblioteki Czartoryskich (sygu. 1885) Nagurczewskicmu na podstawic przeslanck historycznoliterackich. miçdzy innymi wzmianki S. K. Potockiego o nim jako .. Horacyjusza i Homera wicrszem thumaczu" (rps AC (AD) Apl' 233. s. 296. 773 - brulion sylwetek

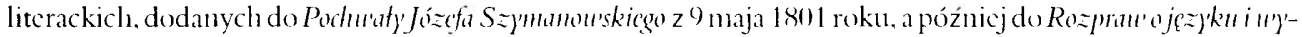
mor'ie polskicj). Wprawdzic w późnicjszych wydaniach Podurnaty'... i Rozpran'... Potocki wymicnia tylko tych autorów, których tlumaczenia Nagurczewskiego wyszly drukiem: Wergiliusza (Bucolica, 175+. 1770), 1778), Cycerona (1763, 1771) i Demostenesa (1774), lub znanc byly szerszej grupic odbiorców (przcklad ks. III-IV dodany do: Iliada Honera ... th. F. K. Dmochowski, t. 3. Warszawa 1801, s. 8(1)-109)). Nicmnicj atrybucj̧ zarów-

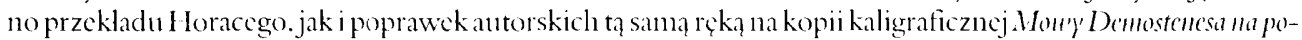
grzebie zolnierzy ateriskich miancj popicram arguncutem neograficznym: autografem profesji zakonncj Nagurczewskiego z 2 lutego 1758 roku. Za uprzejme ndostępnicnic kopii dokumentu z. Archin'mun Romanmm Socictatis Iesu (Lith. 4. 148) dziçkuję serdecznic o. Markowi Inglutowi SJ.

th $\mathrm{O}$ zaniechaniu pracy thumacza nad Homerem pod wplywem przekladu Iliad)' F. K. Dnochowskiego wspo-

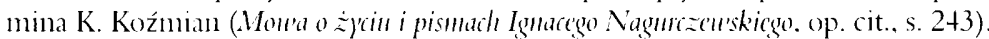

t> Nagurczewski raczej nic tlumaczyl bezpośrednio z greki: w komentarzu powolywal siç wręcz ua francu-

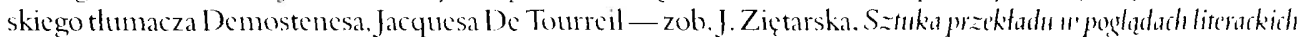
polskiegu Osuricénia. Wrochaw 1969 (Studia z Okresu Oświecenia. t. 10). s. 82-83: eadem. Pod u'ezu'aniem Cy'erona i Horacego, .. Teksty" 1976, $1 \mathrm{r}$ 1, s. 106-108.

${ }^{1 *}$ Rps AGAD ApP 250, s. 140 (w. 65-68): satyrę oglosil drukiem Roman Kalcta, Obiady' caw'antkeu'e na du'orzi

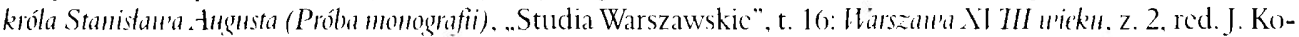
wecki. Warszawa 1973. s. 109-114 (tu cytat na s. 111).

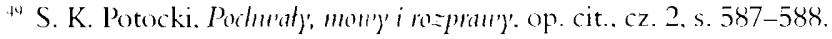


Być może to jedna z przyczyn, dla których Potocki nigdzie nie wykorzystal przedłożonego sobie thumaczenia, chociaż wielokrotnie wspominal Demostenesa i przytaczal wyjątki z jego mów w pracach teoretycznoliterackich ${ }^{511}$.

\section{Quomodo?}

Sajednak i glębsze powody niewykorzystania epitafu Demostenesa, jak również pozostalych greckich przykładów, wynikające właśnie z immanentnych cech wzorca ateńskiej mowy pogrzebowej. Jej schematyczność zakładala lączne traktowanie wszystkich poległych, bez wywoływania ich imion $^{51} \mathrm{i}$ bez różnicowania rzeczywistych zasług. W ślad za badaczami francuskimi ujmie to kilka lat później Ludwik Osiński, którego głos trzeba uznać za reprezentację całego ówczesnego „obozu klasyków”, więc i Stanisława Potockiego, w następujących słowach:

...cóż w sobie mieć mogły ściśle własnego, ściśle odznaczającego się, pochwały, których celem nie był jeden człowiek szczególny, jeden bohater, ale tłum wojowników, razem walczących, razem poległych? Więcej tam dostarczała mówiącemu treści bitwa niż jej bohaterowie, więcej ogólne uczczenie waleczności niż obraz wielkiego czlowicka ${ }^{52}$.

Być może to perspektywa zbyt indywidualistyczna, zastosowana nietrafnie do polis, której zasadą istnienia byl kolektywizm. Ale z punktu widzenia psychologii można się zgodzić z innym spostrzeżeniem wyrażonym przez Osińskiego, że

...częste powtarzanie jednego obchodu osłabiać musiato moc pierwotnego wrażenia; obrazy byly wiclkie, lecz podobne do siebie, obrzęd wspanialy, lecz. zwyczajuy, a z czasem i pospolity ${ }^{53}$.

Powtarzalne było także podkreślanie w epitafach odwiecznej tradycji waleczności jako konsekwencji ustroju polis. Uzwięźlil to w swoim epitafie Demostenes:

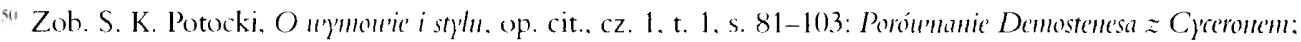

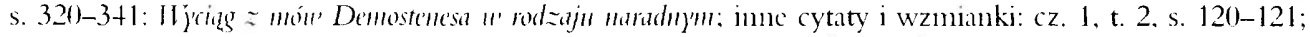
1+t-146: 212-239; cz. 2, t. 3, s. 81-98; 99-139 (tu przeklad polski calości mowy ,chersonejską zwancj", s. $(0+1.38): 1+(0-179$.

"1 Twierdzenie Zygmunta Zapaly. ze Denostenes wymienil w mowic ,.kazde nazwisko” poleglego pod Che-

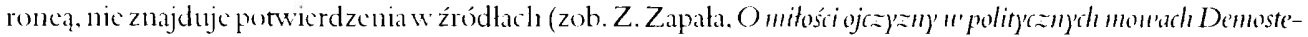
nesa. cz. 1. Kraków 1898. s. 70). Zresztą.. W państwie demokratycznym, jakim byly Ateny, pochwaly imienne obywateli nic mogly wehodzié w rachubę" (M. I terman. Moura pogrzeboura Hyperejdesa.... op. cit., s. 498).

52 L. Osiński. Ifjktad litcratury porín'mantzej [1818-1830], w: idem, Dzieha, t. 4. Warszawa 1862. s. 169-170.

${ }^{53}$ Ibidem, s. $16 \%$.
} 
Co za powody pociągnęły tych mężów do podjęcia pięknej śnierci, jużem przełożył; te są: zacne urodzenie, przystojne wychowanie, nicprzestanne w rycerskich zabawach ćwiczenie się, ksztalt gminowladıego rządu ${ }^{5+}$.

Potocki mógl - i to czynit - nawiązywać do bohaterskich tradycji oręża szlacheckiego, czego symbolem byla postać obrońcy Wiednia i calej chrześcijańskiej Europy, Jana III Sobieskiego ${ }^{55}$. Trudniej niż Demostenesowi byłoby mu jednak poprowadzić tak prostą liniç myślową między „cnotą wojenną” przodków i ustrojem Rzeczypospolitej szlacheckicj. On, generał artylerii z czasów walk w obronie Konstytucji trzeciomajowej (wspótredagowanej przez jego brata Ignacego), wiedzial doskonale, że polskie bohaterstwo lat minionych nieraz wypływało z idei libermm veto, konfederacji i szlacheckiego ekskluzywizmu (jak konfederacja barska), lecz bywało takze (jak powstanie kościuszkowskie lub czyn legionowy) skierowane przeciw podobnym destrukcyjnym czynnikom sensu largo (zniesionym prawnie w 1791 roku). Trudno też byłoby szefowi rządı Księstwa zwanego Warszawskinn dowodzić doskonalości tego absolutnie przejściowego tworu politycznego, w którym nawet realizacja postulatów Konstytucji 3 Maja osadzenia na tronie „elekcyjnym przez familije” dynastii saskiej ${ }^{5 t}$ nie dawala pretekstı do wróżenia mu trwałości.

Chodzito więc o coś inneggo. Waleczność bohaterów z różnych sfer spolecznych (a nawet — jak podpułkownik Berek Joselewicz - etnicznych), która była tylko ich osobistą zashugą, domagała się ich wymienienia podczas wyjątkowej, nicpowtarzalnej uroczystości, i temu służyły oficjalnie przyrządzone raporty i spisy oficerów. Na wstępie Pochu'aty'.. Potocki sformutowat to wprost, modyfikując schemat Demostenejski:

Wspomnę z uszanowaniem imię i zgon ich szlachetny! Cóż nadto na ich pochwałę dodać można? Bo jeżeli najznakomitsi rycerze większej dla ojczyzny ofiary uczynić nie moga, jak śmierć ponieść w jej obronie, nie masz większej nad to wspomnienie pochwały dla mężnych naszych, którzy w nicj polegli ${ }^{57}$.

Z kolei przyczyn tej waleczności nie sposób było zakorzenić wylącznie w przeszłości. Nawet odwołania historyczne, rozsiane w Pochu'ale waleczny'ch Polakón'..., nie mogły przesłonić jasnej prawdy, że walczono z Austrią — u boku Napoleona, lecz samodzielnie — o kraj realnie

") Demost. Epit. log. 27; rps AGAD Apl' 193, s. 53.

55 Do postaci króla nawiązywała inskrypcja na odwrocic bramic triunfahnej. wzniesioncj w Warszawic na uro-

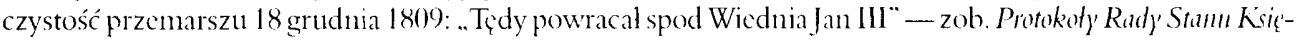
stu'a Lársauskiego, t. 2, cz. 2, wyd. B. Pawlowski i T. Mencel. Toruń 1968, s. 30)7-308 (sesja 455, 12 grudnia $1809)$.

56 „Dynastyja przyszlych królów polskich zaczunic siç na osobic Fryderyka Augusta. dzisicjszego clektora saskicgo, którego sukcesorom de lmmbis z plci męskicj tron polski przcznaczanny" - cyt. za: Konst)tmija 3 Maja

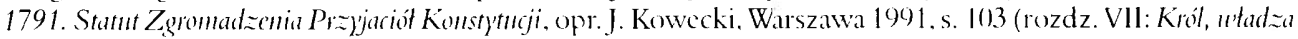
"') ${ }^{\prime}(m a n+\varepsilon a)$.

57 S. K. Potocki, Pochu'ata waleczmy'h Polakóu'... Warszawa 1810, s. 3-4. Lokalizacja cytatów z wydań 1810, 1812, 1816 i rpsu AGAD Apl'233 dalej bezpośreduio w tekścic artykulu. 
istniejący od wieków, kiedyś nam zabrany, ale zarazem o państwo idealne, którego jeszcze nie ma, które ma się dopiero bardziej narodzić niż odrodzić.

Dlatego przeszłość nie ulega w mowie Potockiego mitologizacji, a tym mniej historia najnowsza, wydarzenia będące jeszcze niedawno chwilą bieżącą. Dokonania polskich żołnierzy, opisywane w linearnym porządku chronologii, już od pierwszych słów Pochu'at)'.. jawią się jako dzieło tejże chwili, wynikają z "męstwa narodowego”, ale spełniającego się w ludziach żyjących dziś, zobowiązanych świadomie werytikować swoją tradycję. Ich czyny nie są bynajmniej prostą konsekwencją tej tradycji, lecz twórczym zaprzeczeniem. Wzmiankując niedawne zasługi obrony obywatelskiej, Potocki wyrazi się jasno:

...zbawilo ojczyznę zupełne wasze dla niej poświęcenie się, zbawiła jedność i cnota wasza, jakją niegdyś przodków nierząd i niezgoda zgubiły (1810, s. 16).

Brak też miejsca w mowie Potockiego na metafizykę dziejów. Cnota męstwa nie ma innej sankcji niż czysto ludzka „waleczność narodowa” (1810, s. 3), bez jakichkolwiek odwołań religijnych, nie mówiąc nawet oczywiście o sarmackiej koncepcji antemurale Christianitatis. Z punktu widzenia sfer rządowych malego jeszcze państwa in statu nascendi, mającego nadzieję wejść w skład nowej, zmieniającej się Europy jako coś więcej niż tylko rezerwuar zaopatrzenia obcej armii i przyczólek jej obrony, konieczne było propagowanie ideologii obywatelskiej nowego typu, z wyraźnym ograniczeniem wplywu, traktowanej instrumentalnie, religii na życie publiczne. Pod ty'm względem Pochu'ata... jest konsekwentnie laicka, w czym łatwo dostrzec także inspirację płynącą ze strony ponadnarodowego wolnomularstwa.

Powyższe nie oznacza jednak przemiany Pochu'aty' u'alecznych Polakón'... w obiektywną i suchą relację historyczną. Owszem, mówca nie pomija bitew nierozstrzygniętych (Raszyn, 19 IV) czy porażek (Jedlińsk, 11 VI; kapitulacja Sandomierza, 19 VI), ale jego zadaniem, stosownie do okoliczności świeckiego obrzędı laudacji, jest przecież emocjonalne uwznioślenie czynów żołnierskich. Dokonuje się ono przede wszystkim w warstwie wysłowienia; dlatego też na przykład 1.3 lipca nieprzyjaciel pod Chorostkowem

...schronit się do murowanych gmachów i te wozami zatarasowal (...) (1810, s. 15),

podczas gdy według raportu sztabowego ,zamknąl się w gumnach z trzech stron murowanych”, na które ofiarnie nacieral „osiemnastoletni młodzieniec, hrabia Starzyński” ”̋ .

Potocki nie eliminuje też calkowicie czynników nadprzyrodzonych, lecz ich udział w mowie jest zupełnie marginalny, na poziomie leksyki. Z wyjątkiem bardziej filozoficznej niż religijnej refleksji: 
Zadumiewając się rozum ludzki nad taką zmianą rzeczy, dostrzega w niej zapisaną w księdze wyroków na niewdzięczność i wiarołomność prędzej czy później spaść mającą karę (1810, s. 26)

inne odwotania „metafizyczne” to jedynie figury stylistyczne, opatrzone czytelnymi sygnalami wątpliwości i fikcjonalności:

Zdaje się, iz blade cienie tylu poległych pod tą stolicą Prusaków, powstawszy z grobów swoich, wstrzymywały kroki pobratymców (...) (1810, s. 5);

Nie zdajeż się, iż cień szanowny Jana Zamoyskiego powstal z grobowca i wezwał Polaków na te szańce, które ręka jego na ich obronę wyniosła? (...) Nie zdajcż się, mówię, to widmo rzetelnym, bacząc, jakim, że tak rzekę, cudem 1500 Polaków zdobyło tę warowną twierdzę, od trzechtysiącznego garnizonu pilnie strzeżoną (...)? (1810, s. 12);

...polegl jak godny potomek tylı polskich rycerzów, którzy go pewnic z radością w poczet swój w niebieskich przyjęli sklepieniach (1810, s. 13);

Rzektbyś (...) że piorunująca i groźna postać (...) odpychała go nadludzkim ramieniem (1810, s. 17).

Wszystkie wspomniane wyzej cechy ogniskują się w pierwszym akapicic Podnu'aty....

Pięknym zaiste dla wymowy polem byłoby wystawienie tego, co w tej krótkiej a świeżo ukończonej wojnie zdziałał oręż polski, wskrzeszony twórczym $\mathrm{Na-}$ poleona Wielkiego duchem. Zdaje się bowiem, iż męstwo narodowe, wywołane przez niego z grobowca, w którym go wraz z imicniem Polaka na wieki pogrążonym mniemano, powstało na głos potęzny wskrzesiciela swojego z tą samą dzielnością, której tak świetny, wybawiając niewdzięczny Wiedeń, dało dowód (1810, s. 3).

Z perspektywy kompozycji retorycznej wstęp ten jest początkiem figury myśli epanortesis — sprostowania, gdyż za chwilę, ograniczając swoje zadanie do uczczenia poległych, mówca stwierdzi:

...wspaniały ten obraz w calej swojej świetności nie jest przedmiotem mowy mojej: tkliwa, lecz smutua część jego jest dzisiaj moim udziałemn (1810, s. 3).

Natomiast przez analogię do kompozycji muzycznej, jak w ekspozycji klasycznej formy symfonicznej (w odróżnieniu od której Pochu'ała... jest zresztą tekstem ciągłym, bez podziału na części), pojawiają się tu trzy główne motywy, które zostaną rozwinięte i będą przeplatać się w dalszych partiach mowy.

Najwięcej miejsca zajmuje w Pochu'ale... tytulowy „temat Polaków”, których Potocki na podstawie materiałów sztabowych wymienia pięćdziesięciu trzech, trzy nazwiska dodając 
z własnego pomysłu ${ }^{59}$. To oni na czas wygłaszania tej mowy reprezentują cały naród. Opisując ich śmierć, mówca stara się o różnorodność stylistyczną. Kilkakrotnie — poprzestańmy tu na kilku cytatach — zwraca się do nich bezpośrednio (apostrophe):

Nie zamilczę imion waszych, mężni Świerzawski i Dobiecki porucznikowie (...), ani twojego, mlody i waleczny podporuczniku Zawadzki (...). Nie przepomnę mianowicie ciebie, kapitanie Kossowski, co wyszedłszy z boju ranami okryty, umarłés, żałıjąc tylko, żeś nie mógł drugi raz życia na obronę ojczyzny poświęcić (1810, s. 6-7);

Umarłeś z ran w tej pamiętnej bitwie odniesionych, waleczny kapitanie Murzynowski (...) (1810, s. 8-9);

Ocalal Toruń, lecz ty przy owej bohatyrskiej mostu obronie życia postradałeś, poruczniku Antosiewiczu! (1810, s. 17);

Legleś pod Wrzawą, kapitanie Siemiątkowski, a ciebie, poruczniku Krębski, wkrótce do grobu wtrąciły odniesione tam blizny! (1810, s. 20);

Próżnie was towarzysze wzywają, Kossakowski, Politowski, Chmielewski kapitanowie, próżnie glos wola żolnierzy! Sława im tylko odpowiada: „Polegli za ojczyznę!"*oll . Nie ocaliła was mlodość, nie ocaliło męstwo, Lubiewski, Witwicki, Chludzicki porucznikowie, a powziçte o was szczęśliwe nadzieje wraz z wami do grobu zstapily (1810, s. 23).

Częściowo są to jednak patetyczne frazesy znane z retoryki rozkazów wojskowych, jak zwłaszcza owe „wiclkie”, „szczęśliwe” bądź „świetne nadzieje”, zaleta oficerów, którzy „na tonie zwycięstwa śmierć znaleźli" (1810, s. 29). Syntetycznym przykladem tego podniosłego, a zarazem sformalizowanego już stylı może być zawarty w dokumencie sztabowym opis śmierci pod Almonacid (17 VIII) pułkownika Macieja Sobolewskiego, który

...kazawszy uderzyć do ataku, opanowal prawie w momencie to niedostępne stanowisko, wtenczas kulą uderzony polegl na łonie zwycięstwa i chwaly, a oddając już ostatnic tchnienie, jak drugi Spartańczyk zawolat na swoich: „To nic, dzieci, naprzód, naprzód!”. Tak, zostawując wielki przykład i smutek nieutulony w korpusie, ten oficyjer wiclkich nadziei równie żałowany jest w wojsku, jak i przez samego króla hiszpańskiego".l.

\footnotetext{
"Mówca pominąl dwadzicścia piçć nazwisk ze spisu poległych w Hiszpanii (Alcala, Aranda, Somosierra) ibidem, s. 379)-380.

"W Wrowadzenic zxyczaju apeli poleglych (w Dzicí Zaduszny pod Grobem Nicznanego Żolnierza w Warszawic) Tadeusz Jurga odnosi dopicro do lat 30. XX wicku (zob. T. Jurga, $Z$ dzicjóu upamiętniania czy"nón boha-

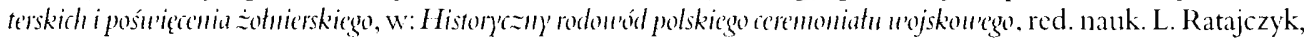
Warszawa 1981. s. 388-394).

6. Rps AGAD Apl 233. s. 377-378 (Lista imicmma...).
} 
Potocki tylko sparafrazował i nieznacznie rozbudowal ten gotowy opis - Sobolewski dokonal czynu „w okamgnieniu”, w swojej prozopopei zawarł jeszcze wezwanie: „....nic to, dzieci, byleśmy pobili, naprzód, naprzód!", po czym — mówca konkretyzuje tu postać „Spartańczyka” - „godną Epaminondasa wyzionąl duszę” i „polegt, głośnym Naczelnego Wodza i samego króla hiszpańskiego zaszczycony żalem" (1810, s. 28; w 1816 wzmianki o królı brak). Podobnie atakujący Sandomierz 18 maja książę Marceli Lubomirski, podpulkownik, „wielkich nadziei szef batalijonı”, zgodnie z listą sztabową (co prawie dosłownie powtórzy Potocki)

Trafiony w piersi kulą karabinową, ofiarowanego pardonu nie przyjął, a drogo przedając życie swoje nieprzyjacielowi, bagnetami skłuty żyć przestal ${ }^{12}$.

To właśnie on „poległ jak godny potomek tylu polskich rycerzów” — ale tę wyjątkową koncesję mówcy na rzecz arystokratyzmu usprawiedliwia nie tyle samo nazwisko, co czyn oficera; zresztą w rękopisie (s. 357) byl on początkowo tylko ich „krewniakicm”. Podobnie „śmiercią goduą tak mężnego rodu” (1810, s. 27) zmarł w Madrycie wspomniany już wczeŚniej kapitan 1)ziewanowski, lecz to niewątpliwie aluzja do ofiarodawcy listu, pulkownika, kładąca na pewno silniejszy akcent na „męstwo” niż ,ród” Dziewanowskich.

Na szczególna uwagę zashuguje apostrofa do Polaka, którego Demostenes nie nazwalby „rodzonym synem” tej ziemi, czego z kolei zupetnie nie podziela Potocki, stosujący w obecności słuchaczy - z niewątpliwą intencją dydaktyczną - ponadetniczne, obywatelskie kryterium narodowości:

Ty pierwszy braterską ziemię twoim zasmucileś zgonem, o waleczny podpułkowniku Berko, gdy cię niecierpliwego zwycięstwa wśrzód nieprzyjaciela zbytnie uniosło męstwo! Kock, który się rodem twoim chelpil, chełpić się będzie i grobem. Pomścili towarzysze twoi, pomścilo natychmiast zwycięstwo zabójczej śmierci twojej, lecz cóż ją ojczyźnie nagrodzić zdoła? Pomni ona i dawniejsze za nią blizny i walki twoje, pomni wiecznie, żeś ty pierwszy dał un nas przyklad odżywionej waleczności narodowi twojemu i wskrzesil wizerunek rycerzów, których śmierć niegdyś Syjonıı opłakiwaly córy! (1810), s. 11)

Oczywiście autor mowy z zasady nie różnicuje zasług poleglych, zgodnie z whasną aporią (retorycznym zwątpieniem):

Czemuż w ciągu tej krótkiej mowy wynienić imion i wyszczególnić czynów nie mogę każdego żohnierza, którego na placu sławy śmierć pozazdrościla ojczý́nie! Jakiżkolwiek byl w wojsku stopień jego, zgon dowiódl, iż imienia rycerza był godzien (...) (1810, s. 7). 
Wydaje się jednak, że mówca pragnie wzbudzić szczególną sympatię słuchaczy do czterech spośród postaci, przy których zatrzymat się trochę dłużej. Reprezentują one poniekąd nową, równą w obowiązkach i prawach strukturę obywatelską rodzącego się, wielonarodowego państwa. Primi inter pares byliby więc: „mężny i uczony Godebski” (1810, s. 6), wspomniani wyżej podpułkownik Berek Joselewicz i „Marceli książę Lubomirski”, a także „,nieodżałowany trębacz Borysiewicz" (u Potockiego: Borysowicz, 1810, s. 15),

...w każdej akcyi szczególnie dystyngwıjący się, znany w armiji z swej brawury i przytomności (...). Nieprzyjaciel, dowiedziawszy się o śmierci jego, którego męstwa mial w stracie swojej dowody, śmierć tę rozkazem dziennym publikować kazal ${ }^{1,3}$.

Nie wszystkie nazwiska pobudzały jednak Potockiego do rozbudowanych opisów czy apostrof, nie każdy z „rycerzów” mial też wystarczająco szczególowe dossier, dlatego wielekroć epitety, którymi operuje mówca, czynią wrażenie „blankietowych”, wymiennych, rodem z kancelarii pulkowych. Zapewne jednak znajomość tego stylu wśród słuchaczy wystarczała, by wlaściwie odczytać zabiegi stylistyczne Potockiego: jako patos usprawiedliwiony, daleki od chęci retorycznego popisu.

Jeśli mówca pozwala sobie na ozdobniki, jest to nadal wzbogacanie pierwszego,,tematu Polaków”, i to przemyślane, bo odwołujące się do bohaterskich aspektów kultury antycznej, zaszczepionej głęboko w świadomości polskiej. Już na początku, po sprecyzowaniu tematu, Potocki przypomina obyczaj ateńskich mów pogrzebowych:

Wdzięczność i poszanowanie publiczne powinny być ich nagrodą, jak byly u Greków, podczas kiedy Milcyjades, Arystydes, Focyjon lub Perykles ${ }^{6+t}$ oddawali imieniem narodu hołd wimny pochwal i wdzięczności zbawcom Grecyi, w sławnych od tylu wieków bitwach poległym (1810, s. 4).

Następny akapit jest porównaniem wojen perskich do wojny polsko-austriackiej, ukazujący — bardzo ryzykownie z perspektywy historii, lecz celnie z punktu widzenia wyobrażeń potocznych - przewagę naszego pokonania „z dawna ćwiczonych, rządnych i bitnych” Austriaków nad zwycięstwem tych, którzy „,barbarzyńskie zmiękczałych Persów pokonali hufce” (1810, s. 4). "Jak stogłówna hydra, którą przecię Herkulesowe wojowników naszych zwaliły ramiona" (1810, s. 19) odradza się zresztą wojsko austriackie dzięki posiłkom z Moraw i Węgier. Produktywne okazuje się też odwolanie do Lacedemonu. „Spartańską ożywiony odwaga” jest „wódz nasz na czele ośmiotysiącznego wojska” (1810, s. 5), „mężem spartańskiej stałości" porucznik Karassowski poległy pod Tarnopolem (1810, s. 14); o Sobolewskim-Epaminondasie już wspomniano. Do legendarnej tradycji rzymskiej należy przypomnienie „Cyncynatów naszych” w Wielkopolsce (1810, s. 18). Warto jednak zauważyć, że paralela „Sa-

\footnotetext{
6.3 Ibidem, s. 38.3 .

th Wyd. 1816, s. 297: Milcyjades, Arystydes. Perykles lub Demostenes.
} 
ragossa - nowy Sagunt" pozostała tylko w szkicu rękopiśmiennym (s. 368) - widocznie Potocki uznal wzıniankę o mieście iberyjskim zdobytym przez I Iannibala w 219 r. p.n.e. (costato się bezpośrednią przyczyną drugicj wojny punickiej) za niezbyt czytelną dla ogólu sluchaczy.

Do znanej za to mitologii I Iomerowej odwołuje się porównanie trojańskie, w którym pojawia się rzeka Skamander (zwana też Ksantos — 'Żólta'):

Rzekłbyś, że jak nowy Ksant Wisła walczyła z nieprzyjacielem za lıbą ojczyznę (...) $(1810$, s. 17)

Potocki nie stroni zresztą od porównań homeryckich - będących tu wyznacznikiem raczej rodzimej niż antycznej elokucji, więc nadal wzbogacających „temat Polaków”:

Lecz jak burza w ciemnej nocy jaśniejąca piorunami odwieczne wywraca dęby lub jak potok śniegami nadęty w przepaścistą wali się dolinę i wszystko z sobą porywa, tak mala liczba rycerzów naszych napada na austryjackic szańce, które z licznych dział piekielıy wyziewają ogień (1810), s. 9-10);

Polegl zacny mlodzieniec [scil. Marceli Lubomirski - J. W.], jak pada pod kosa kwiat ranny, łzami jutrzenki skropiony, lecz poległ śmiercią zazdrości godną, bo sławą okryty (...) (1810, s. 13);

Jako skała, o którą się rozbijają rozhukane wiatrami morskic bałwany, a ona niewzruszoną stoi, tak o szańce Sandomierza kruszyły się następujące jedne po drugich zapalczywego nieprzyjaciela szyki (1810, s. 21).

Mówiąc o środkach stylistycznych (oczywiście nie sposób wyszczególnić tu wszystkich użytych przez autora figur i zabiegów!), warto wspomnieć o widocznej w mowie Potockiego perseweracji metafory „wieńca”. Mogłaby ona dodatkowo przemawiać za prawdziwym brakiem czasu na zredagowanie Pochu'aty'..., gdyby nie fakt, że spotykamy ją co kilka kart we wszystkich wydaniach:

...tąż samą, bo równie zasłużoną, z laurów korona, znanych mi i dotąd nieznanych rycerzów naszych, wodzów i żohnierzy, za ojczyznę poległych, wickopomny wieńczę grobowiec (1810, s. 7; 1816, s. 303);

Powiedzieć można, że noc 3 maja pozazdrościła wiekopomnej sławie dnia tego, a raczej, że go męstwo polskie przyozdobić chciało czynem równie w wojnie, jak ustawa 3 maja w pokoju paniętnym, i w świetny ten dzień laurową wraz z dębową uwieńczyć ojczyznę koroną (1810), s. 10; 1816, s. 308);

Wieńczmy grób jego [scil. Marcelego Lubomirskiego - J. W.] laurami, na którym lzy czule ronią krewni i ojczyzna! (1810, s. 13-14; 1816, s. 313-314); 
Dwie mi dziś tylko wolno rozdać laurowe korony imieniem Towarzystwa naszego (...) jedną grobowiec zmarłych, drugą skronie żyjących wieńczę polskich rycerzów (1810, s. 31; 1816 tekst przeredagowany, s. 339 [właśc. 341]).

Dodajmy, że pod koniec mowy ,temat polski” występuje pod postacią „motywu hiszpańskiego" i „niemieckiego” (czyli odwołującego się do walk Polaków na ziemiach Austrii i krajów niemieckich).

Drugi dający się w'yodrębnić „muzyczny” temat Pochu'at' ... nazwać można śmiało thema regium, bo jego symbolem jest Jan III Sobieski. Stanowi on, by tak rzec, basso continuo i zarazem ramę kompozycyjną calej mowy, a pojawia się w dwóch splecionych ze sobą „liniach melodycznych": „wilanowskiej”, nawiązującej do miejsca zamieszkania mówcy, i „wiedeńskiej”, którą ująć można formułą "niewdzięczności Austrii”. Akord „wilanowski” wybrzmiewa w drugiej polowie i w finale mowy. Najpierw jest to apostrofa:

W jednej z nich [scil. potyczek - J. W.], nieopodal wiejskiego Jana III siedliska, życia postradaleś, waleczny kapitanie Burski; wojenna cię trąba do boju z domowego wywołała zacisza. Spoczywasz w godnym męstwa grobie, pod cieniem wawrzynów ręką bohatyra szczepionych (1810, s. 19).

Na końcu zaś Potocki sklada (spełnioną później) obietnicę pod adresem „szanownych cieni" poleglych:

W siedlisku króla bohatyra, pod cieniem tych drzew niebotycznych, pod którym spoczywal zbawca Wiednia, wyryję na twardym glazie imiona wasze i slawę ich obok sławy Jana III ku czci wiecznej poświęcę $(1810 \text {, s. 30) })^{\text {hs. }}$.

W „temacie wiedeńskim” nigdy nie słychać (o przyczynach tego juz wspomniano) akcentów „przedmurzowych". Zakładane przez Potockiego porozumienie ze stuchaczami odwołuje się do Sobieskiego jako ratownika kultury europejskiej i człowieka czynu zbrojnego, a nie opatrznościowego obrońcy chrześcijaństwa. Niewdzięczność Austrii jest tu zjawiskiem politycznym, nad którym można ubolewać, choć jednak - byla o tym mowa wcześniej - jego ukaranie wyglądać może na urzeczywistnienie zapisu w „księdze wyroków”...

To jednak tylko retoryczny ozdobnik. Mowa Potockiego jest i w tym konsekwentna, że zmagania wojenne przedstawione sa jako męskie rzeniosło, zadanie trudne, ale podporządkowane zasadom honoru. Wojna jest tu elementem świata tylko realnego, niemal nieuniknionym narzędziem polityki, złem koniecznym, wyjściem ostatecznym jedynie jako walka obronna. Tylko dwukrotnie pojawia się w mowie pojęcie „zemsty”: w apostrofie do Berka Joselewicza (gdzie wartościowanie pozytywne przełamane jest zaraz zwątpieniem) i w przypo-

\footnotetext{
6. Autorstwo projektu wilanowskicgo pomnika bitwy raszyískicj przysądza siç Piotrowi Aignerowi (zob. W. Fijalkowski, Dziahalnosic Stunistun'a Kostki Potockicgo u' Wilanou'ic, ..Bulctyn Historii Sztuki: 34, 1972, nr 2. il. na s. 147), monografista architekta nic wymienia jednak monumentu wśród jego prac (zob. T. S. Jaroszewski, Chlin'stian Piotr Aigner, Warszawa 1970).
} 
mnieniu bitwy pod Wrzawami (tu: „Wrzawą”, 11-13 VI), gdzie Austriacy okazali się „chciwi zwycięstwa, rozjuszeni wstydem i zemstą" (1810, s. 20). Poza tym jednak Austriacy zawsze nazywani są w Podhu'ale... „nieprzyjaciólmi”. W świetle całej mowy oznaczać to może — etymologicznie - 'kogoś, kto nie jest przyjacielem', ale nie można odrzucić moźliwości, że nim będzie.

W tym miejscu pora przejść do omówienia trzeciego i z pewnością najciekawszego „motywu muzycznego" Podhuaty..., czyli „tematu Napoleona”. Jest to bowiem właściwy motyw przewodni, wysokimi fanfarami powracający na przestrzeni calego utworu - i zarazem przedmiot najwiçkszych, najboleśniejszych zapewne dla autora, zmian.

Okazuje się bowiem, ze Potocki przed wznowieniem Pochu'at' u'aleczmy'ch Polakóm'... w roku 1816 dokonal znaczących przeróbek tekstu. Częściowo są to tylko zmiany językowe, świadczące o dążeniu autora do polszczyzny czystej, rodzimej. Wymianie podlegly przede wszystkim terminy techniczne związane z wojskowością, o źródłosłowie lacińskim, w języku polskim zadomowione, lecz jednak zastappione bardziej rdzennyni odpowiednikami. „Akcja” to w wyd. 1816 ,bitwa”; ,atak” i pochodne — „napad”, „natarcie”, „uderzyc”" (każdy zamiennik pojawia się dwukrotnie); „armaty” — „działa” (czterokrotnie); „bateria” — „działobitnia”; oddziały „formujące się" — „ksztalcące się” lub „wzrastające”; „forteca” — „warownia”; „garnizon” — „osada”; ,heroiczny”- „bohaterski”; ,kampania” — . wojna”; , kapitulacja”„umowa”; „kawaleria” — ,jazda”; ,kolega” — „towarzysz”; „neutralnośc” - „bezstronność”; „pardon” — „poddać się”; „pozycja” — „miejsce”; "rekruci” — „howozaciężni”; „szef” „naczelnik”. Poza ścisłą tematyką wojskowości pozostaje określenie „fanatyczny”, zastąpione przez „szalony”, aczkolwick kontekst dotyczył wojny, która mogliby wzniecić Austriacy na terenach niemieckich, gdyby udato się im zawładnąć Ksiçstwem (1810, s. 25; 1816, s. 331 [właśc.: 333]).

Terenem najważniejszych przemian tekstu jest jednak dwanaście miejsc węzłowych, związanych imiennie bądź peryfrastycznie z postacią „największego z ludzi”, nadającego wydarzeniom historycznym walor jeśli nie metafizyki, to w każdym razie nadludzkiego niemal geniuszı. Po „upadku dumnego” gasną jednak w mowie Potockiego wszelkie odwolania do wskrzesicielskiej i „duchowej” aktywności Napoleona. On sam zniknąl już z pierwszego akapitu: „oręż polski, acz tak świeżo wskrzeszony”, nie zawdzięcza mu odrodzenia, a „męstwo narodowe” zostało przez inną silę ,jakby wywolane z grobowca”. Był to zew „obrony nowej ojczyzny”. Już nie „największy z ludzi” prowadził „mężnych naszych” — to oni sami „wrócili” i ,nauczyli w domu pozostałych" zwyciężania i zdobywania nowych, a w zasadzie dawnych terytoriów, których nam „pozazdrościla przemoc”. To jedno z micjsc, gdzie następuje też wyraźne zredukowanie wartościowania etycznego polityki. „Waleczności narodowej” nie ćmi już „los zawistny”, lecz „przeciwny”; wspomniana wyżej „przemoc” zastąpiła dotychczasową „nienasyconą chciwość” sąsiadów. Nieprzyjaciel (czyli Austria) jest tylko „sąsiedzki” (to sprawdzalny, obiektywny fakt), nie zaś „wiarołomny”. To może się przecież zmieniać z czasem stąd też w innych miejscach mowy złagodzenie brutalnych określeń pod adresem „band” i „spisków” Niemców, powstających przeciw Napoleonowi (1810, s. 25), zamienionych 
w szlachetniejsze „roty” i „zmowy”, a także wzmianka o ,pobratymskim narodzie”, który w druku byt „sprzymierzonym wojskiem” (1810, s. 20), zaś w brulionie tylko „Moskalami”, w których bezczynnej .przytomności” "st pod Wrzawami wykrwawiali się Polacy.

Nie ma juz wcale w nowym wydaniu antykizującej paraleli:

Jak Rzym zwyciężyl Kartaginę, tak pierwszy świata genijusz sądzi, że Polak Austryjaka zwalczyć powinien (1810, s. 11).

Teraz, jeśli ... śpieszy wojsko nasze pokonać nieprzyjaciela w własnych jego granicach (...),

nie czyni tego „na ten wyrok”; zwycięstwo towarzyszące żohnierzom jest „powolne głosowi słuszności”, a nie „zawsze posluszne głosowi bohatyra” (ibidem).

Nad Zamościem nie błyska już grom, rzucany na Austriaków „potężną Wielkiego Napoleona ręką”, tylko „sprawiedliwej pomsty”. Dlatego też nie tylko „cień szanowny Jana Zamoyskiego", lecz i „szczęśliwa Zamoyskiego gwiazda” pojawi się ponad walczącymi — oczywiście w miejsce gwiazdy Napoleona.

Jeszcze wyraźniej „Wielki Napoleon” odepchnięty zostanie od bram Wiednia, dokąd wkraczal w „piorunującej i groźnej” postaci, a jednocześnie „odpychał nadludzkim ramieniem" Austriaków od Wisły-Skamandra. Tym razem należne miejsce zająl na polskim niebie zajął „powstały z grobu oswobodziciel niewdzięcznego Wiednia” o postaci „piorunującej, groźnej i mściwej”. Autor uznał więc, że należy wzmocnić „temat wiedeński” Jana III nawet kosztem powtórzenia bez zmian formuly ze wstępu — po to, by Subieskiego przywrócić do whaściwych kompetencji, niechby nawet $\mathrm{w}$ ramach figury stylistycznej o walorach jedynie fantazji.

Teraz więc nie „pierwszy świata genijusz”, tylko „męstwo polskie” wyznaczyło nieprzyjacielowi dzień ucieczki z Księstwa. Teraz (1816) nic czas roztaczać wzniosły obraz z połowy lipca roku 1809:

Tegoż prawie dnia wspaniały zwyciężca Austryjaków i Dunaju, dozwalając zawieszenia broni, znękanemu i już upadku bliskiemu nieprzyjacielowi okazał, że wśrzód ponyślności wojny żąda błogosławieństw pokoju, który nadać lub odrzucić był panem. Zawieszenic to broni zbawilo Austryjaków na brzegach Wisły równie jak nad Dunajem, wyrywając z rąk Polaków pewne prawie nad uciekającym nieprzyjacielem zwycięstwo (1810, s. 25).

Wystarczy stwierdzić sucho:

to Rps AGAD Apl' 233, s. 41)2. 
Tegoż prawie dnia stanęlo w Wiedniu zawieszenie broni, które wyrwało z rąk Polaków pewne prawie nad uciekającym nieprzyjacielem zwycięstwo (1816, s. 330 [właśc. 332]).

Inaczej też po latach usprawiedliwić można militarno-żandarmeryjne zaangażowanie w Hiszpanii:

O jednęż tam co nad Wisłą i Dunajenn walczy Polak sprawę; szuka w najoddaleńszych krainach whasnej ojczyzny, bo mu los ten jedyny dźwignienia jej środek wskazuje (1816, s. 333 [właśc. 335]).

Los, a nie Napoleon, którego otaczaly w 1809 roku furie złych i miłość dobrych:

O jednęż tam co nad Wisłą i Dunajem walczymy sprawę, bo miota wszędy wściekła zazdrość wojnę na obaleniè wielkości Wskrzesicicla naszego, to jest na obalenic jedynej bytu naszego podpory. Bijemy się tam w whasnej sprawie, choć się zdajemy święty wdzięczności pełnić tylko obowiązek (1810, s. 26).

Najwięcej zmian nastappilo więc pod koniec mowy, w części podsunowıjąccj i wyjaśniającej sens wydarzeń. W roku 1809 enocje mówcy i oczekiwany entuzjazm shuchaczy zdawaly się dosięgać zenitu:

O szlachetnie w Niemczech i I Iiszpaniji polegli rycerze nasi! Wy, których wymieniłem, i wy, których dotąd mi nieznane rozglosi slawa imiona, dziclni dowódzcy i mężni żołnierze! Niech groby wasze w oddalonych krainach będą wiecznym pomnikiem wdzięczności Polaków ku Wskrzesicielowi swojemu. O, bodajbyśmy nią świat caly napełnić mogli i zrównać dobrodziejstwu wysługą! Gdy to jest rzeczą niepodobną, bodajby się wspaniaty nasz dobroczyníca przekonał, że nic takiego nie mamy (nie wyłączając życia), czego by mu nie poświęciły wdzięczność i przywiązanie nasze! (1810, s. 29)

W roku 1816 w tym samym miejscu też grają emocje — lecz jest to zmiana bodaj najbardziej istotna, jako bolesna refutacja mozliwych zarzutów pod adresem także samego mówcy:

Niech groby wasze w oddalonych krainach będą wiecznym pomnikiem przywiązania waszego do ojczyzny i prac chwalebnych, coście ku jej dźwignieniu z taką wytrwałością i przez lat tyle przedsiębrać śmieli. Nie, nie byliście cudzej woli ślepym narzędziem, lecz wola wasza zawsze i we wszystkin do tego dążyła, byście odzyskali ojczyznę, a w tym względzie nic się wam trudnym, nic niepodobnym nie zdalo (1816, s. 337 [wlaśc. 339]).

Warto dodać na marginesie, że dysponujemy ciekawym świadectwem oddziaływania mowy Potockiego na współczesną literaturę, podobnego w charakterze do zmian, jakim pod piórem autora ulegla sama mowa. Świadectwem tym jest redakcja „C” Duman żotnierza polskiego... Kantorberego Tymowskiego, ogłoszona w „Pamiętniku Warszawskim” z 1815 roku, 
a napisana — w myśl informacji autorskiej — w roku 1810. Jak dowodzi badaczka, słynny wiersz nie powstal jednak „w starożytnym zamku Maurów” gdzieś w Hiszpanii, lecz najpewniej w Warszawie, najwcześniej w II połowie 1811 lub w 1812 roku, a rozbudowana wersja "C" wręcz w roku jej publikacji.

Nie ma wątpliwości, że 32 dodane w 1815 roku wersy są parafrazą pochwały Potockiego, który pełnił przecież ważną rolę w życiu Tymowskiego, był jego szefem i protektorem, wzorem moralnym i estetycznym ${ }^{67}$ -

zauważa monografistka poety, śledząc przemianę osobistego wiersza refleksyjnego, będącego pochwalą Legii Nadwiślańskiej, w zobiektywizowaną mowę pochwalıą „całego polskiego, sarmackiego oręża”, z jednoczesnym podkreśleniem moralnej dwuznaczności walki przeciwko Hiszpanom broniącym własnego kraju ${ }^{\text {tox }}$. Jedenaście nazwisk bohaterów, zaczerpniętych z mowy Potockiego, byłoby zatem symbolicznym uczczeniem całego polskiego ,rycerstwa”, które nie powinno już polegać wyłącznie na Napoleonie, lecz na własnych silach, jakie umie z siebie samodzielnie wydobyć.

\section{Cur?}

Historyk wymowy starożytnej przypomina sytuację po Cheronei:

Po zwycięskiej bitwie Filip podyktowal Atenom warunki pokojowe stosunkowo lagodne. Ateny nie utraciły niepodlegtości, uległ jedynie rozwiązaniu Związek Morski, a państwu ateńskiemu pozostawiono kilka wysp (...). Floty ateńskiej nie zmniejszono. Demostenes - niepoprawny optymista — nie rozstawał się z nadzieją lepszej przyszłości, a ta nadzieja dodawała mu zapału do dalszej działalności w służbie ojczyzny, działalności, ze względu na ówczesną sytuację, przede wszystkim administracyjnej. $(\ldots)^{6,9}$.

Historyk współczesny podkreśla, że podczas trwania wojny polsko-austriackiej Rada Stanu pod prezesurą Stanisława Kostki Potockiego trwała w bezczynności i pogłębiającym się niezdecydowaniu. Już pierwszego dnia, 15 kwietnia, w odezwie do mieszkańców Księstwa nie wspomniano nawet o Napoleonie, zostawiając pole manewru do ewentualnych rokowań z najeźdźcą, arcyksięciem Ferdynandem d'Este. Tegoż dnia Potocki wystosował do króla saskiego i księcia warszawskiego Fryderyka Augusta list dowodzący bezradności władz i braku nadziei na ponyślne rozwiązanie zaczynającego się konfliktu. Po kapitulacji Warszawy Rada Stanu przeniosła się do Torunia (gdzie odbyla sesję już 28 kwietnia), a następnie (od 18 maja) do Tykocina, w poblize granicy rosyjskiej, co powszechnie odbierano bardzo nieprzychylnie.

\footnotetext{
67 E. Wichrowska. Jest Hiszpania za gérami... Fatszy'n') trop elegii Kantorberego Ty'mon'skicgo, .Prace Polonistyczuc", scria 56 , Lódż 2001 , s. 56.

ox Zob. ibidem, s. 49-57.

(19) R. Turasicwicz. Ilstep w: Demostenes, Hyor móm, op. cit. s. XLIV.
} 
Jeszcze z Torunia (w liście do króla z 10 maja) Rada sformulowala krytykę posuwania się wojska polskiego pod dowództwem ks. Józefa Poniatowskiego w gląb Galicji, choć zarazem problem obrony kraju zawsze składała chętnie na barki ministra wojny ${ }^{70}$. W świetle tych faktów, wybranych spośród wielu podobnych, konieczność zorganizowania w grudniu oficjalnych obchodów ku czci „zwycięskiego wojska” i zabrania na nich głosu przez wybitnego mówcę, lecz słabego podczas wojny polityka Potockiego, bez cienia energii i zdecydowania księcia Józefa, zakrawa na ironię losu, a dyskusje nad wystawieniem brany triumfalnej (z napisem polskim, „który by każdy żołnierz mógł zrozumieć”, zamiast inskrypcji laciúskiej) tcliną groteską̧ ${ }^{71}$.

Historii rozumianej jako suma faktów, jako rachunek dokonań i zaniechań, zmienić się nie da, zawsze jednak można - i świadomy retor wie o tym doskonale — inaczej ją opowiedzieć, a nawet kazać inaczej brzmieć wypowiadanym kiedyś stowom. Wzorzec takiego postępowania, wprawdzie nie w oryginale (zachowane bruliony dowodzą, że nad autorani greckimi pracował za pośrednictwem języka francuskiego) ${ }^{72}$, Stanisław Potocki z pewnością znal.

Technikę przytaczania - a w rzeczy samej tworzenia - przemówicí, zamieszczanych w kolejnych partiach Wojny peloponcskicj, sam jej autor ujmuje następująco:

Co nicktórzy I Hellenowie na czele ruchu ówczesnego stojący w pewnych razach i w pewnym położeniu wedle największego podobieństwa do prawdy mó w i ć mo gli, to staralem się oddać, trzymając się co do głównej myśli jak najblizej tego, cow rzeczy samej powiedzieli ${ }^{73}$.

Jaki miał w tym cel? Pisarz historii „chciał prawdę idealnąz z realną połączyć i pogodzić”wyjaśnia dziewiętnastowieczny thumacz, i dodaje zwięźle:

Czym są w dramacie greckim chóry, tym w historii Tucydydesa są mowy, glosy objawione przed dokonaniem wielkich akcyj historycznych, już naprzód konieczność i doniosłość ich poznać dające ${ }^{7+}$.

W zamyśle Tukidydesa tragicznym kontrapunktem dla epitafu, pełnego głębokiego przekonania o potędze demokracji ateńskiej. a głoszonego na kartach dziela przez wspóltwórcę owej potęgi, jest zatem, w dalszych rozdzialach tej samej księgi, wstrząsający opis zarazy

73 Zob. B. Pawlowski. op. cit., s. 121-126, 277-284, 404-411.

${ }_{71}$ Zob. Protokot)' Rady' Stamu Księstura Warszan'skicgo, loc, cit.

72 Zob. przykladowo rps AGAD Apl 250, s. $438-4+49$ (brulion thunaczenia Filipiki Demostenesa z francuskicgo), s. 450-459 (nickompletna kopia czystopisowa).

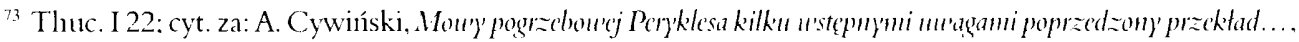
..Bibliotcka Warszawska” 1861, t. 4, z. 11, s. 281: tu miçdzy innymi analiza i krytyka thumaczenia Historii u'ojmy' peloponeskicj Tukidydesa (z. 1, Poznań 1861) Antonicgo Bronikowskicgo (s. 287-291: whasny przcklad Anastazego Cywińskiego epitafi Peryklesa: s. 291-302).

${ }^{74}$ Ibidem, s. 282. 
w Atenach. Epidemia niebawem przyniesie śmierć samemu Peryklesowi, będąc także katastrofą ludzkiej moralności i peryklejskich ideałów ${ }^{75}$.

Podobnie pierwsza część Pochu'at, móu' i rozprau', jeśli potraktować ją jako świadomie skomponowaną całość, wyraźnie wybrzmiewa tonami coraz głuchszymi. Po epitafium dla brata, zmarłego w Wiedniu jako emisariusz narodı u „Człowieka Przeznaczenia”, następują świadectwa załamywania się kolejnych polskich „wielkich nadziei”. Ich upostaciowaniem są dwaj oficerowie: pulkownik Adam Potocki symbolizuje dramat odwrotu z bezkresów Rosji polskich oddzialów, tworzonych niedawno z takim entuzjazmem; książę Józef Poniatowski - przegraną nie tylko „bitwę”, lecz wręcz „wojnę narodów” ”.

Pisana z myślą wygłoszenia jej na Wawelu (do czego nie doszlo) mowa pogrzebowa ku czci księcia Józefa nie pozwala słuchaczom wątpić we właściwą hierarchię postaci opatrznościowych, którą juz skorygował czas. Okazıje się, że niedawny „najwiçkszy z lıdzi” zesłany został, owszem, przez Boga — ale po to, by jako „nieznany we Francyi cudzoziemiec” na „krwawym i rozwalonym, który dźwignął, Burbonów tronie” poskromil „szaloną mądrość” bezbożnej rewolucji, zapoczątkowanej przez „nieszczęśnych fillozofów ośmnastego wieku”;

Lecz kiedy, od poludnia do pólnocy krwawe rozciągając ramiona, powstał znienacka przeciw ulubionemu od Boga monarsze, którego on cnotom pokój świata i jego pociechę w przyszłości powierzył, runęła cala wielkość jego, jednym tchem Boga zmieciona $(\ldots)^{77}$.

Jak zatem mogto dojść do tego, że l'olacy czuli w „krwawych ramionach” Napoleona ojcowski uścisk? Potocki thumaczy rzecz najprościej (choć z użyciem retorycznej apostrofy w pierwszym i figury słownej poly'ptote, przeniesienia, w ostatnim z cytowanych tu zdań):

Wskrzeszenie ojczyzny, święte dla Polaków godło, jedyna i upragniona ich nadziejo, jakżeż chciwie, choć może mniej bacznie przyjętą zostałaś! Lecz podała nieszczęściu rękę nadzieja, które się ślepo tej swojej ostatniej podpory chwyciło! Wreszcie, nie mógł nie uwieść glos zwycięzcy, który, mocen wszystko nakazywać, obiecywal wszystko, a dokonać wszystkiego zdolnym zdawal się ${ }^{78}$.

Być może więc Stanisław Kostka Potocki, bardzo daleki od „niepoprawnego optymizmu” Demostenesa, wolał zostać raczej gorzkim Tukidydesem naszego „Peloponezu”, Europy odtrąconej i rozbitej na przedpolach Azji... Wznawiając w 1816 roku Pochu'ate u'alecznych Polakóu'..., próbowal zapewne dać świadectwo owym dawnym narodowym nadziejom. Uczynił

\footnotetext{
75 Zob. Thuc. II 48-53; por. R. Turasiewicz, H'step w: Demostenes, Wybir móm, op. cit., s. LXXX.

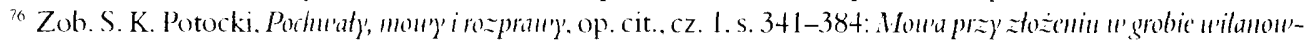

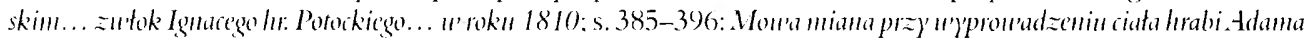

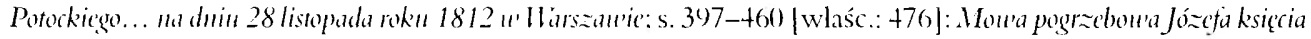
Pomiatouskiego... na obchód pogrzedu jego un Krakourí... napisana... | czytana w Towarzystwie Przyjaciól Nauk 30) IV 1816].

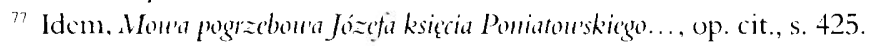

${ }^{78}$ lbidem, s. +26.
} 
to jednak, mając w pamięci, kto zaczął przewodzić wówczas naszej części kontynentu. Zdecydowal się więc na znaczne przesunięcie akcentów myślowych i emocjonalnych kosztem integralności opublikowanego wcześniej tekstu. Elocutio przegrała z inu'entio, stowo z myślą; ,realnej" prawdzie tworu retorycznego, będącego efektem kreacji, przeciwstawiona została prawda ,idealna”, wynikająca z nowych złudzeń, marzeń i wyrachowania.

Dlatego po latach istotnicjsze od tego, co naprawdę mówiono w krótki grudniowy dzień w kaplicy Pałacu Saskiego o bohaterstwie Polaków u boku Napoleona, okazało się to, co w mającym dopiero pojawić się kontekście obu późniejszych epitafiów z tegoż woluminu dla pulkownika Potockiego i księcia Józefa, czyli metaforycznie dla Berezyny i Lipska pow in no by ło, tam i wtedy, zostać powiedziane. 